\title{
小児顎骨骨折の臨床的研究
}

\author{
中村雅明
}

\section{A clinical study of maxillary fracture in children}

\section{Masaaki NAKAmura}

\begin{abstract}
Clinical and radiographic examinations were made of 60 children with jaw fractures which we treated in the past 17 years. Follow-up examinations were made of 33 of these 60 patients. The results obtained are as follows:

Clinico-roentgenographically,

1) Traffic accidents were the chief cause of jaw fractures.

2) Of these 60 children, there were about 3 times as many boys as girls.

3) Five to six-year-old children experienced jaw fractures most frequently.

4) Some changes were observed in likely sites of fracture by age-groups, however, so far as the condylar fracture is concerned, all age-groups experienced such fracture frequently.

5) From the therapeutic viewpoint, many of fractures in the horizontalramus were treated by the conservative technique, and all of the cases with only fracture of the mandibular condyle were so treated.
\end{abstract}

From the viewpoint of follow-up examinations,

1) Root malformations were observed in 6 of 28 permanent teeth germs present on the line of fracture just suffered.

2) Of these 6 teeth germs, 4 were cases where open reduction was performed at the same sites. In all cases, malformation occurred on simple rooted teeth, and 5 teeth were found unfinished in preparation of crown.

3) Morphological abnormality of the mandibular condyle was observed in 3 of 13 fracture of mandibular condyle cases.

4) However, no jaw underdevelopment and/or joint dysfunctions were observed.

Key words: jaw fractures in children, mandibular condyle, long-term follow-up

緒

\section{$\overline{\overline{\bar{D}}}$}

小見の顎骨肖折については，小児の成長に伴ら行動様 式の変化や環境の変化等により年路や性別等において差 があり，また，顎骨の発育や歯胚の発育に関連して骨折 部位等に変化があるのではないかと思われる。また，治 療に関しても顎骨が発育中であり，とくに growth center を有する下筫頭部は成人より優れた自己修復能力を

久留米大学医学部口腔外科学講座

（主任：朱雀直道教授）

Department of Oral Surgery, Kurume University

School of Medicine (Chief: Prof. Chokudo Sujaku)
持っていること，また顎骨中に発育中の永久柬歯肧があ ることなど生理的, 解剖学的特異性から治療法に十分な 配虑をする必要があるといわれている1 99. その上小見 といっても乳幼兒から学童期まで分けられ，それぞれに 応じた治療法があってもよいように思われるが，明確な 答えは出ていないまた，小児の钼骨骨折に関する臨床 的検討は少なく，遠隔成績についての詳紐な報告もさら に少ない,8 ${ }^{814)}$.

そこでわたくしは，小罗顎骨骨折の治療法の確立を目 的として, 当教室で取り扱った15歳未満の小児䫇骨骨折 について臨床的X線学的に整理検討し，また，予後調查 を行い若干の知見を得たので報告する。 


\section{第 I 編 臨床的 $\mathbf{X}$ 線学的研究}

\section{研 究 対 象}

対象は1961年 1 月から，1977年12月までの17年間に， 久留米大学付属病院口腔外科を受診した 15 藏未満の峘胃 骨折（歯慒骨骨折単独を除く）60症例である。しかし， X線学的検討は骨折線が確認できた上罘では 1 例, 下顎 では59例中の53例を対象とした。

\section{研 究 方 法}

症例分析には，外来および入院記録ならびにX線写真 を用いた。

$\mathrm{X}$ 線写真としては, 後頭一前頭位撮影，バノラマX線 叞影，下顎骨斜位，䫇関節左右側方位，眼䆻関節方向 位，咬合法、口内撮影法などを用いて調査した。

すなわち，臨床統計的には，当科の特徽を知ることと 他の比較を行うために，またX線学的には，小児の顓肖 は成人に比へ，頸骨骨質の硬度が低く，弾性的で柔軟で ある。また骨折を起こす際に，歯小趾の存在も関係があ るのではないかと思われるため骨折部位に特異性がある かどらかをX 線学的に分析してみた。ささらに治療法で は，小児の顎骨骨折の治療においては，解剖学的，生理 学的, 歯牙の萌出やウ蚛の状態などの問題から, 治療法 を考虑する必要があるといわれている。そこでこれらの 患者について，次の項目につき調查した。

\section{I . 臨床統計的分析}

1. 小児顎骨骨折の例数と頻度

2. 性別, 年秢別

3. 受賃原因と性別，年柃別
4. 年次別推移

5. 月別分布

6. 合併損賃

\section{II. $\mathbf{X}$ 線学的観察}

1. 部位別

1）上罘霄，骨折

2）下顎骨”骨折
(1) 正中部
(2) 切霜部
（3）犬歯小臼歯部
(4) 大臼歯部
(5) 顎関節突起部

2. 下顎骨骨折の增路に伴万変化

III. 治療法

表 1 小児顎骨骨折患者の頻度

\begin{tabular}{l|r|r}
\hline 小児顎骨骨折患者数 & 60 例 & \multicolumn{1}{|c}{$\%$} \\
\hline 顎骨骨折患者総数 & 414 & 14.5 \\
小児患者総数 & 4,228 & 1.4 \\
小児外管患者数 & 169 & 35.5
\end{tabular}

表 2 小児䫇骨骨折患者の性別扰よび年秢

\begin{tabular}{c|r|r|r}
\hline & 男 & 女 & 計 \\
\hline $0 \sim 2$ 藏 & 5 & 2 & 7 \\
$3 \sim 4$ & 5 & 1 & 6 \\
$5 \sim 6$ & 12 & 3 & 15 \\
$7 \sim 8$ & 6 & 4 & 10 \\
$9 \sim 10$ & 3 & 2 & 5 \\
$11 \sim 12$ & 4 & 2 & 6 \\
$13 \sim 14$ & 9 & 2 & 11 \\
\hline 計 & 44 & 16 & 60 \\
\hline
\end{tabular}

表 3 小児顎骨省折の原因と年路㧊上び性别

\begin{tabular}{|c|c|c|c|c|c|c|c|c|c|c|c|c|c|c|c|c|}
\hline & \multicolumn{2}{|c|}{ 自動車 } & \multirow{2}{*}{\multicolumn{2}{|c|}{$\begin{array}{ll}\text { 転 } & \text { 落 } \\
\text { 男 } & \text { 女 }\end{array}$}} & \multirow[t]{2}{*}{ 転 } & \multirow{2}{*}{$\frac{\text { 倒 }}{\text { 女 }}$} & \multicolumn{2}{|c|}{ スポーツ } & \multicolumn{2}{|c|}{ 自転本 } & \multicolumn{2}{|c|}{ 欧 打 } & \multicolumn{2}{|c|}{ その他 } & \multicolumn{2}{|c|}{ 計 } \\
\hline & 男 & 女 & & & & & 男 & 女 & 男 & 女 & 男 & 女 & 男 & 女 & 男 & 女 \\
\hline $0 \sim 2$ 歳 & 1 & 2 & 3 & & 1 & & & & & & & & & & 5 & 2 \\
\hline $3 \sim 4$ & 3 & & 1 & & 1 & & & & & & & 1 & & & 5 & 1 \\
\hline $5 \sim 6$ & 8 & 1 & 1 & & & 1 & & & 2 & & & & 1 & 1 & 12 & 3 \\
\hline $7 \sim 8$ & 2 & 3 & 3 & & 1 & & & & & & & & & 1 & 6 & 4 \\
\hline $9 \sim 10$ & 1 & 2 & & & 1 & & 1 & & & & & & & & 3 & 2 \\
\hline $11 \sim 12$ & & & 3 & & & 1 & & & & 1 & 1 & & & & 4 & 2 \\
\hline $13 \sim 14$ & 6 & 1 & & & & & 2 & 1 & & & 1 & & & & 9 & 2 \\
\hline 小 計 & 21 & 9 & 11 & & 4 & 2 & 3 & 1 & 2 & 1 & 2 & 1 & 1 & 2 & 44 & 16 \\
\hline 計 & & & & & & 6 & & & & 3 & & & & 3 & & \\
\hline
\end{tabular}




\section{研 究 成 績}

\section{I . 臨床統計的分析}

1. 小児顎骨骨折の例数之頻度

過去17年間に当科を受診した，歯槽骨骨折単独例を除 く罘骨骨折患者 414 例中, 15藏未満の小児は60例（14.5 \%)であった。 また，同年間に受診した小睍患者総数は 4, 228 例で，その $1.4 \%$ 占めていた（表 1)。㴿骨骨折 を上下別にみると，下䫇骨骨折単独例が最も多く 58 例 (96\%) で，上顎骨骨折単独例と上下顎骨骨折がおの括 の 1 例 $(1.7 \%)$ であった。

2. 性別および年龄別に関する分布（表 2)

性別は男児 44 例，女罗16例で男女比は，2.8:1 で男 児に多かった，発症年㖪を 2 歳ごとに区分し，その分布 をみると， 5 〜 歳は15例，13〜14歳は11例と多く，9 〜 10歳は 5 例, 11〜12歳は 6 例と少なかった. 最小受傷年 秢は11か月の乳児の下顎骨正中部骨折の症例であった。

3. 受傷原因と性別, 年夦別との関係

受賃原因は表 3 に示すごとく, 自動車事故が30例と半 数を占め, 次いで転落事故が多くみられた。

年齢との関係は，自動車事故では各年齡層にみられる が, $5 \sim 6$ 歳が最も多く 9 例, 次いで13〜 14歳が 7 例であ った。 また，学童期においては年齢層が大きくなるにつ れ発症件数は減少していた，転落，転倒も各年齡層に発 症しているが，年秢層による差はみられなかった。自動 車事故は $5 \sim 6$ 歳に，スポーツによるものは 9 藏以上の 年龄にみられた，性別との関係では，その他を除き，い ずれも 2:1〜3:1 の割合で男児に多かった。しかも転 落に执いては全例が男児であり，その場所は家屋 2 階か らのものが 6 例で, その他家屋 3 階, 物干台, 木の上, 川土手が各 1 例見られた。
表 4 自動車事故の分類

\begin{tabular}{|c|c|c|c|c|}
\hline 香少 相手 & なし・絴物 & ハイク & 車 & パイク・車 \\
\hline 遊戲・步行中 & 0 & 2 & 13 & 1 \\
\hline 自 転 車 & 0 & 3 & 4 & 0 \\
\hline 車に同乗 & 2 & 0 & 3 & 0 \\
\hline : $\quad$ ク & 1 & 0 & 0 & 0 \\
\hline 不 & 1 & 0 & 0 & 0 \\
\hline
\end{tabular}

自動車事故の内訳は表 4 に示す.

\section{4. 発症の年次別推移}

年次的発症例数をみると, 後半に若干增加の傾向が認 められた（図 1)。原因別との関係は若干自動車事故の 増加が認められるも，はっきりした関連は認められなか った。

5. 発症の月別分布

事故発症の月別症例数は 4 月 10 例， 3 月，10月，11月 の 7 例が多く， 2 月が最も少なく 1 例， 1 月， 9 月， 12 月も 3 例と少なかった，季節的にみて，最も寒い12月， 1 月，2月が少なくなっているようである（図2）。

\section{6. 合併損賃}

他部合併損㑺は，全症例中 $38 \%$ にみられ，その内訳は 表 5 のごとくであり, 頭部外傷が 20 例と最も多くみられ た（表 5 ).

意識坒失は 14 例にみられ，8例が 1 時間以内の軽症例 であったが，2 日以内 1 例， 3 日以上 2 例と重症例もみ られた。

\section{II. $\mathbf{X}$ 線学的観察所見}

1. 部位別

1) 上顎骨骨折

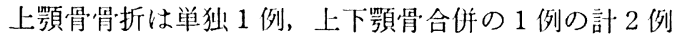

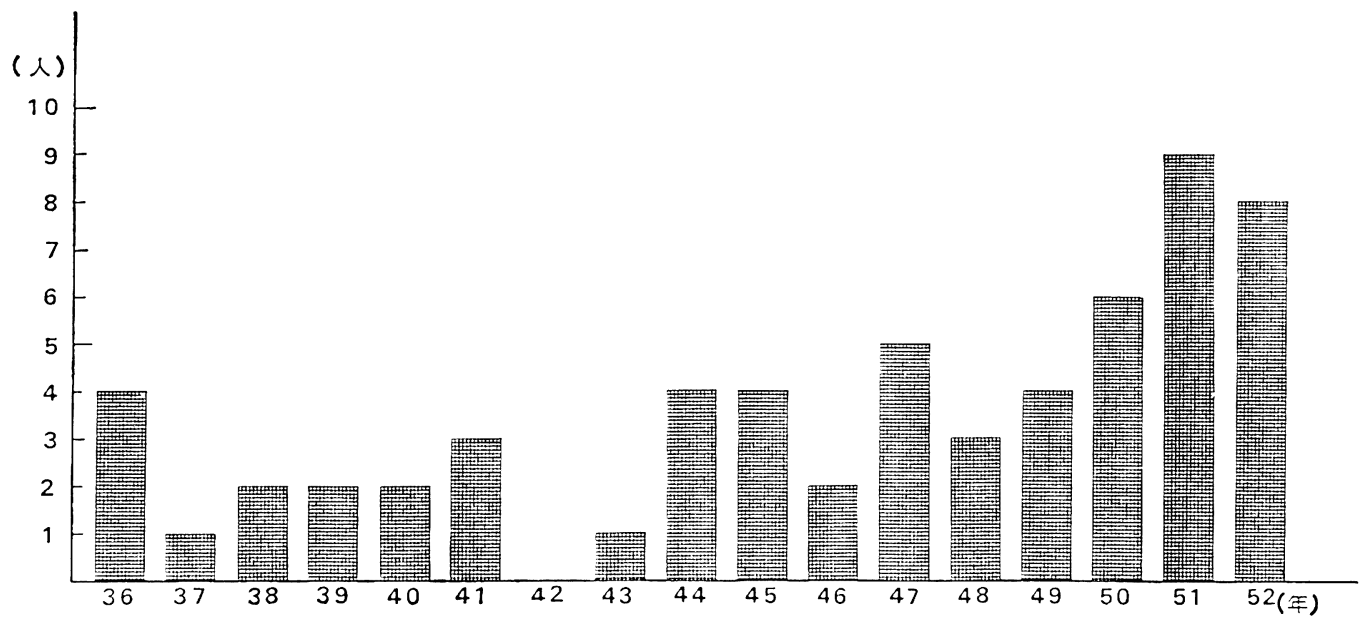

図:1 小児钼骨骨折の年度别症例数（炤和 36 年 1 月 52 年 12 月） 


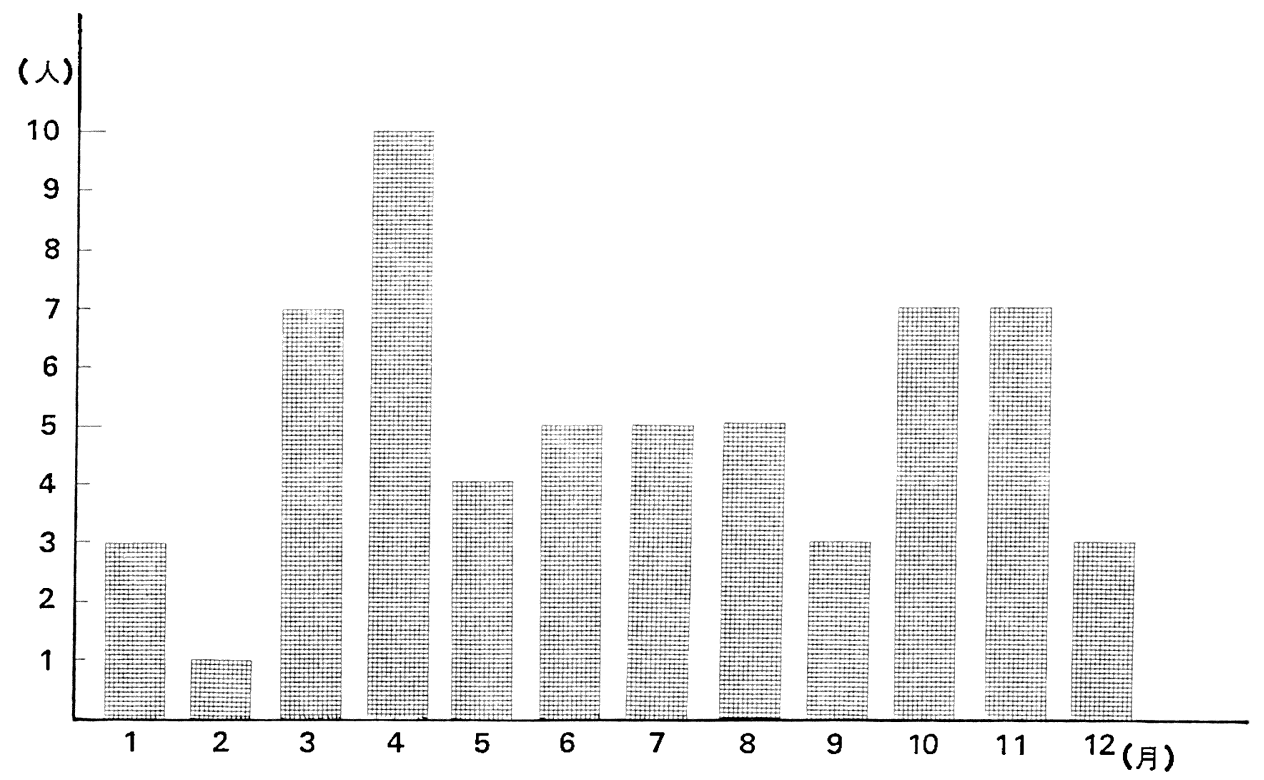

図 2 小児顎骨骨折の月別変化

表 5 合併症

\begin{tabular}{|c|c|c|}
\hline \multirow[t]{5}{*}{ 頭部外傷 } & 頭蓋骨骨折 & 1 例 \\
\hline & 頭蓋底骨折 & 1 例 \\
\hline & 頭部裂傷 & 1 例 \\
\hline & 頭部打撲 & 3 例 \\
\hline & 意識聚失 & 14例 \\
\hline \multirow[t]{4}{*}{ 他部骨折 } & 銧骨骨折 & 1 例 \\
\hline & 胁骨骨折 & 1 例 \\
\hline & 第 1 中手骨基底部骨折 & 1 例 \\
\hline & 大眼骨骨折 & 2 例 \\
\hline \multirow[t]{9}{*}{ その他 } & 外傷性眼球陌凹 & 1 例 \\
\hline & 鎖骨脱臼 & 1 例 \\
\hline & 鎖骨打撲 & 1 例 \\
\hline & 上腕部唑偟 & 1 例 \\
\hline & 时関節部裂甥 & 1 例 \\
\hline & 左手首打擈 & 1 例 \\
\hline & 下艆部挫愎 & 1 例 \\
\hline & 下腿部打掽 & 2 例 \\
\hline & 漛関節打擈 & 1 例 \\
\hline
\end{tabular}

で，最小受傷年龄は 2 歳であった。1 例は陳旧例で覦折 線が不明であったが，他の 1 例は Le Fort I 型であっ た.

\section{2) 下買骨”骨折}

下頞骨骨折は単独58例, 上下顎骨合併 1 例の計59例で, 本項に损いてはX線写真にて骨折線を確認できたもの53 症例81骨折線を観察し，各発症部位に拈ける骨折線の走
行と歯肧ならびに下顎骨の構造などの解剖学的特異性拉 よび受傷原因との関連について検討した，なお，症例の 内訳は, 単純骨折32例, 重複骨折21例で, 骨折線の内訳 は, 犬畨小田歯部が最も多く28本，次いで関節突起部が 22本，正中部13本，大田崡部括よび切菌部が㧍のおの 7 本, 下顎角部拉よび，上行枝部が括の括の 2 本であった。

(1) 正中部

この部の骨折は 5 歳以下の 症例に多く，2 藏以下で は, 関節突起骨折単独を除く全例に正中部骨折を有し, 4 〜 歳ではそれぞれ30\%に同部の骨折を有していた。 骨折線の走行は，多少屈曲しているが，下縁部より $\overline{1 \mid 1}$ 歯胚間を通り，歯槽頂へ向かって直線状に走っていた。 また，同部骨折に扮ける偏位は比洨的少なかった。

(2) 切歯部

この部の骨折は $3 \sim 5$ 歳に多くみられ，1～2 個の歯 小黼を通っていたが，さほど複雑な走行は示していなか った。

(3) 犬勘小四部

この部の骨折は，6藏以降の聇例に多く，米小霞を有 する症例は14例 ( $6 \sim 11$ 藏), 骨折線数 15 本で, その骨

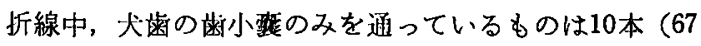

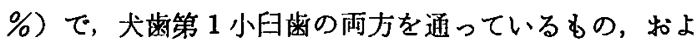
び第 1 小四潾のみを通っているものは，それぞれ2 本で $13 \%$ ，第 2 小臼菌のみ通っているもの 1 例（7\%）であ った。

(4) 大臼部

この部の骨折は比較的少なく，3歳以下の症例にはみ られなかった，打撲部位との関係では，值逢と介達はほ 

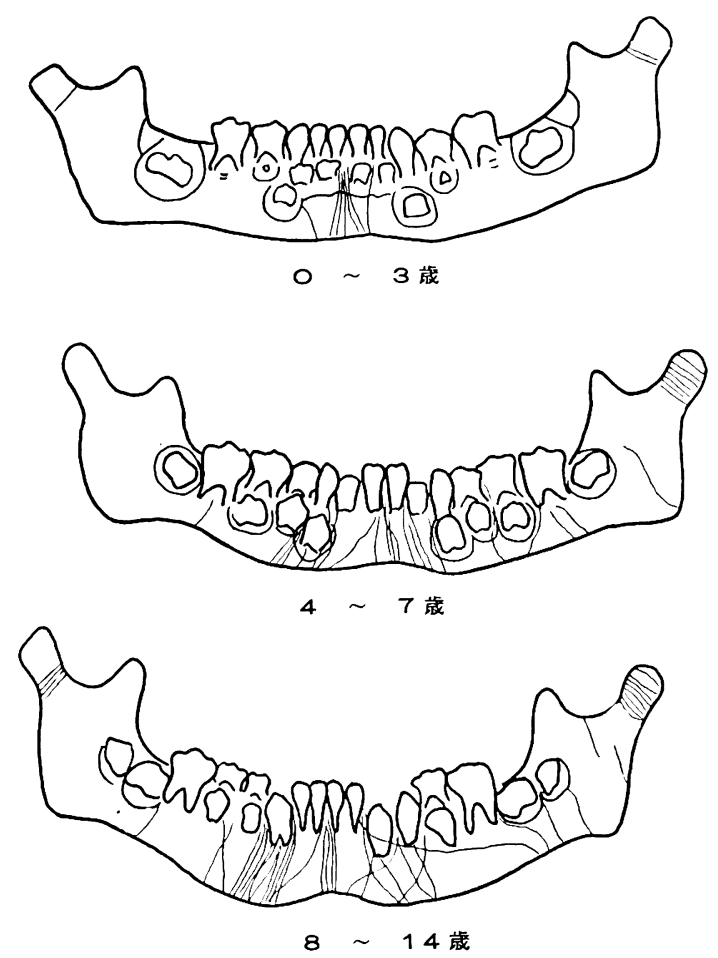

図 3 年粭と下䫇骨骨折線の分布

ぼ半々で, 歯肧のあるものでは下縁部から歯肧へ直線的 に骨折線がみられた。

\section{(5) 顎関節突起部}

この部の骨折は，下顎骨骨折 59 例中 20 例と34\%を占 め, 左側かi15例, 右側 3 例, 雨側 2 例と, 左側に圧倒的 に多くみられた。骨折の種類を MacLennan の分類 ${ }^{15)}$ でみると, 偏位のないもの 2 例, 偏位骨折 5 例, 転移骨 折 2 例, 脱曰骨折13例であった。骨折方向をみると, 全 て内方か内前方への骨折であった。

骨折部位を関節突起頸部の位置でみると，高位で骨折 しているもの 9 例, 低位で骨折しているもの13例で, 高 位での骨折は脱臼骨折に多く，低位での骨折は偏位骨折 に多くみられた。

2. 下顎骨骨折好発部位の增秢に伴ら変化

下敛骨骨折59例中，X線写真にて骨折線を確認できた もの53例について発症部位を各年秢ごとに検討すると， 骨折好発部位が存在し，しかも增路的に好発部位の变化 がみられた。これらを清田 ${ }^{8)}$ の結果と比较するために同 しく< 4 歳未満, $4 \sim 7$ 歳, $8 \sim 14$ 歳の 3 年柃層に分けて 検討した。 1 骨折線を 1 線で表記し，幽胀，歯牙との関 連を中心に模式化した骨折線の分布を 3 つ歯路層で示 した（図了）.

1) 4 歳未涩

8 例10骨折線の分布をみると，正中部が 5 線（50\%）
表 6 下顎骨骨体骨折例での受傷より 初彮までの期間

\begin{tabular}{|c|c|c|c|c|c|}
\hline & 当 日 & $\begin{array}{l}1 \widetilde{\text { 日目 }} \\
\text { }\end{array}$ & $\begin{array}{cc}8 & \text { 日 } \\
\text { 以 }\end{array}$ & 不 明 & 郭 \\
\hline 覞血的整復 & 2 & 7 & 7 & 0 & 16 \\
\hline 非微血的整復 & 10 & 16 & 0 & 0 & 26 \\
\hline 整復の要なし & 1 & 3 & 4 & 1 & 9 \\
\hline 郭 & 13 & 26 & 11 & 1 & 51 \\
\hline
\end{tabular}

表 7 下顎骨骨体部骨折の固定法

1. 睍血的整復を行ったもの

搔爬十囲絖結热

2 例

骨䋃合十囲繞結然

9 例 (1)

骨繾合十連続楿牙結禁

4 例 (2)

骨䋖合 +2 莱結禁

1 例

2. 非観血的整復を行ったもの

連続茵牙結炎

11例 (2)

囲繞結禁

7 例 (1)

三内式副子

4 例 (2)

2 菌結禁

弾力包帯

1 例 (1)

願 帽

1 例 (1)

（）内は顎関節突起骨折合併例

3. 慗復の必要がなかったもの

9 例 (1)

表 8 顎関節突起部骨折単独例の処置

1. 非観血的整復および固定

連続㐘牙結禁法にてゴム牽引

（内 1 例に 5 日間の金属線による顎間固定） 4 例

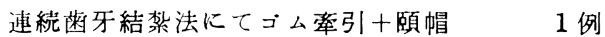
碩 帽

2. その他

\begin{tabular}{lr}
$\begin{array}{l}\text { 温湿布, 開口練習 } \\
\text { 経過钼察 }\end{array}$ & 1 例 \\
& 1 例 \\
\hline & 計 2 例
\end{tabular}

と最も多く，次いで顎関節突起部の 3 線 (30\%), 切歯 部の 2 線 $(20 \%)$ と全て前茵部と須関節突起部にみられ た。骨体部の骨折線は全て永久幽料胚部を通るか，ある いは接していた。

2) $4 \sim 7$ 歳

この年代は 19 例 28 骨折線で, 犬歯小田歯部が 9 線 (32.1\%) と約 $1 / 3$ を占めていた。次いで,䪽関節突起部 7 線 $(25 \%)$, 正中部之切画部が各々 4 線 $(14.3 \%)$, 大臼 
表 9 再来院症例

\begin{tabular}{|c|c|c|c|c|c|c|c|c|c|c|}
\hline $\begin{array}{l}\text { 症例 } \\
\text { No. }\end{array}$ & $\begin{array}{l}\text { 珄 } \\
\text { 別 }\end{array}$ & $\begin{array}{l}\text { 受稘 } \\
\text { 年齢 }\end{array}$ & $\begin{array}{l}\text { 受懏 } \\
\text { ～初診 }\end{array}$ & $\begin{array}{l}\text { 再来時 } \\
\text { 年 哺命 }\end{array}$ & 経過 & 受賃原因 & 打撲部位 & 骨折部位 & 整復法 & $\begin{array}{l}\text { 固定法 } \\
\text { その他 処置 }\end{array}$ \\
\hline 1 & M & 14 & 1 日 & 30 & 16 & 交通事故 & 左侧頓部 & 左下顎角部 & 非観血的 & 連続读牙結禁 \\
\hline 2 & $\mathrm{~F}$ & 13 & 7 日 & 26 & 13 & スポーツ & 右隅角部 & $\overline{76}$ | 間 & 峴血的 & $\begin{array}{l}\text { 骨縫合 } \\
\text { 囲繞結漹 }\end{array}$ \\
\hline 3 & $\mathrm{~F}$ & $11 \mathrm{M}$ & 10日 & 13 & 12 & 転倒 & 左煩部 & $\begin{array}{l}\text { 左顎関節突起部 } \\
\text { 左煩骨弓骨折 }\end{array}$ & 整復せず & 䋖帽 \\
\hline 4 & M & 6 & 当日 & 18 & 12 & 交通事故 & $\begin{array}{c}\text { 左側筫骨骨体部 } \\
\text { ～隅角部 }\end{array}$ & $\overline{\mathrm{C}}|,| \overline{6}$ 部 & $\begin{array}{l}\text { 整復の要 } \\
\text { なし }\end{array}$ & 経過観察 \\
\hline 5 & $\mathrm{~F}$ & 9 & 18日 & 19 & 10 & 交通事故 & $\begin{array}{l}\text { 左顎下部 } \\
\text { 頙下部 }\end{array}$ & $\begin{array}{l}\text { 正中部 } \overline{\mathrm{C}} \text { 部 } \\
\text { 左側顎関節突起部 }\end{array}$ & $\begin{array}{l}\text { 整復の要 } \\
\text { なし }\end{array}$ & ソラックス \\
\hline 6 & M & 6 & 35 日 & 15 & 9 & 交通事故 & 右願部 & $\overline{\mathrm{C}}$ 部 & $\begin{array}{l}\text { 整復の要 } \\
\text { なし }\end{array}$ & 経過钼察 \\
\hline 7 & $\mathbf{M}$ & 2 & 1 日 & 11 & 9 & 転落 & 願部～願下部 & 正中部 & 钼血的 & $\begin{array}{l}\text { 骨絴合 } \\
\text { 囲繞結槂 }\end{array}$ \\
\hline 8 & $\mathbf{M}$ & 7 & 6 日 & 16 & 9 & 転落 & $\begin{array}{c}\text { 右下䫁骨骨体部 } \\
\text { ～頣下部 }\end{array}$ & 左顎関節突起部 & $\begin{array}{l}\text { 整復の要 } \\
\text { なし }\end{array}$ & 開口練習 \\
\hline 9 & $\mathrm{~F}$ & 8 & 3 日 & 16 & 8 & 交通事故 & 左顎下部～頣部 & $\overline{2 C}$ 部 & 非観血的 & 連続菌牙結禁 \\
\hline 10 & $\mathrm{~F}$ & 5 & 6 日 & 13 & 8 & 交通事故 & 左側隅角部 & $\overline{b c}$ 部 & 観血的 & $\begin{array}{l}\text { 骨痛合 } \\
\text { 用繞結禁 }\end{array}$ \\
\hline 11 & $\mathrm{~F}$ & 10 & 19日 & 18 & 8 & 交通事故 & $\begin{array}{l}\text { 右眼窩下部〜頓部 } \\
\text { 左眼䶎下部 } \\
\text { ～顎下部 }\end{array}$ & $\overline{43} \mid$ 間 & 覞血的 & 囲繞結禁 \\
\hline 12 & $\mathbf{F}$ & 2 & 11日 & 9 & 7 & 交通事故 & 頋部 & 正中部 & 钼血的 & $\begin{array}{l}\text { 骨䋖合 } \\
\text { 囲繞結慗 }\end{array}$ \\
\hline 13 & M & 11 & 3 日 & 18 & 7 & 転落 & 顚下部 & $\begin{array}{l}\text { 正中部 } \\
\text { 両側顎関節突起部 }\end{array}$ & 非钼血的 & 三内式副子 \\
\hline 14 & M & 12 & 1 日 & 19 & 7 & 本落 & 下ロ唇部～願部 & $\begin{array}{l}\text { 正中部 } \\
\text { 左側顎関節突起部 }\end{array}$ & 非観血的 & 弾力包带 \\
\hline 15 & $\mathbf{M}$ & 4 & 当日 & 10 & 6 & 交通事故 & $\begin{array}{l}\text { 下ロ唇・䪶部 } \\
\text { ～左口角部 }\end{array}$ & $\overline{\mathrm{ab}}$ 間 & 非観血的 & 囲纘結愁 \\
\hline 16 & $\mathbf{M}$ & 6 & 当日 & 12 & 6 & 交通事故 & 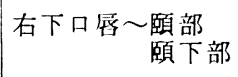 & $\overline{\mathrm{dc}} \mid \mathrm{F}^{\mathrm{y}}$ & 非観血的 & 三内式副子 \\
\hline 17 & M & 4 & 4 日 & 10 & 6 & 交通事故 & 不明 & 左側顎関節突起部 & 非観血的 & 連続茵牙結禁 \\
\hline 18 & $\mathbf{M}$ & 2 & 5 日 & 7 & 5 & 転落 & 左下顎骨骨体部 & $\sqrt{\mathrm{bc}}$ 間 & $\begin{array}{l}\text { 整復の要 } \\
\text { なし }\end{array}$ & 経過観察 \\
\hline 19 & $\mathbf{F}$ & 8 & 38日 & 13 & 5 & 交通事故 & 不明 & $\overline{2 \mathrm{C}}$ 部 & $\begin{array}{l}\text { 整復の要 } \\
\text { なし }\end{array}$ & 経過锥察 \\
\hline 20 & $\mathrm{M}$ & 12 & 1 日 & 16 & 4 & 没打 & 右骨体部 & $\overline{32}|,| \overline{67}$ 部 & 非観血的 & 連続菌牙結禁 \\
\hline
\end{tabular}


の臨床総括表

\begin{tabular}{|c|c|c|c|c|c|c|c|}
\hline 自覚 & 顅貌 & 開口 & 顎運動障害 & 骨折部菌牙所見 & 骨折部X線所見 & 蔽 列 & 合併症 \\
\hline - & 正常 & - & $\begin{array}{l}\text { 側方左右差 } \\
\text { 左へ+1 mm }\end{array}$ & & & 正常 & $\begin{array}{l}\text { 意識消失 } 20 \text { 分 } \\
\text { 左右下肢摖過偣 }\end{array}$ \\
\hline - & 正常 & - & - & & & 正常 & \\
\hline - & 正常 & - & $\begin{array}{l}\text { 側方左右差 } \\
\text { 右へ+2 mm }\end{array}$ & & & 下顎正中右へ偏位 & \\
\hline - & 正常 & - & $\begin{array}{l}\text { 側方左右美 } \\
\text { 左へ+2 mm }\end{array}$ & $\begin{array}{l}\overline{3} \mid \text { 蔯根奇形 } \\
43 \mid \text { 石灰化全 }\end{array}$ & & 下顎正中右へ偏位 & \\
\hline - & 正常 & - & - & & & $\frac{3+3}{3+3}$ で切端咬合 & \\
\hline - & 正常 & - & $\begin{array}{l}\text { 側方左右差 } \\
\text { 右へ }+9 \mathrm{~mm}\end{array}$ & & & $\overline{3 \mid 3}$ 唇側傾斜 & $\begin{array}{l}\text { 意識消失 } \\
\text { 頭部打撲 }\end{array}$ \\
\hline - & 正常 & - & - & & & 正常 & \\
\hline - & 正常 & - & $\begin{array}{l}\text { 側方左右差 } \\
\text { 右へ+4 mm }\end{array}$ & & & $\begin{array}{l}\overline{5} \text { 舌側傾斜 } \\
\text { 下硕正左側へ } 2 \mathrm{~mm}\end{array}$ & \\
\hline - & 正常 & - & $\begin{array}{l}\text { 側方左右差 } \\
\text { 左へ+3.5 mm }\end{array}$ & & & 正常 & \\
\hline - & 正常 & - & - & | 3 类根奇形 & & $\mid \overline{3}$ 遠心傾斜 & $\begin{array}{l}\text { 上膊部 (下银部) } \\
\text { 挫份. 意識消失 }\end{array}$ \\
\hline - & 正常 & - & $\begin{array}{l}\text { 側方左右差 } \\
\text { 右へ+1 mm }\end{array}$ & & & $\begin{array}{l}\overline{3} \mid \text { 欠損. } \\
\overline{7} \sim 4 \mid \text { 近心移動 } \\
\overline{2} \mid \text { 遠心傾斜 } \\
\underline{2} \mid \text { 唇側 } \underline{3} \mid \text { 舌㑡転移 }\end{array}$ & \\
\hline- & 正常 & - & - & 11米根奇形 & & $\overline{3}$ 捻転 & \\
\hline - & 正常 & - & - & & & & 意識消失 \\
\hline - & 正常 & - & - & & $\mid$\begin{tabular}{|l} 
患側顎関節頭形態 \\
常 \\
型顎関節頭
\end{tabular} & & \\
\hline - & 正常 & - & - & & & 上顎前突 & \\
\hline - & 正常 & - & - & $\begin{array}{l}\overline{4} \text { 若冠部石灰化 } \\
\text { 霜根奇形 }\end{array}$ & $\begin{array}{l}\text { 患側顎関節頭形態 } \\
\text { 賞股様顎関節頭 }\end{array}$ & $\begin{array}{l}\text { 下顎正中 } \\
\text { 若千右へ偏位 }\end{array}$ & \\
\hline - & 正常 & - & 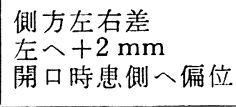 & & & & \\
\hline - & 正常 & - & $\begin{array}{l}\text { 側方左右差 } \\
\text { 右へ+1 mm }\end{array}$ & & & & \\
\hline - & 正常 & - & - & & & & $\begin{array}{l}\text { 意識消失 } \\
\text { 頭蓋骨骨折. 脳挫偒 }\end{array}$ \\
\hline - & 正常 & - & - & & & 反対哜合 & \\
\hline
\end{tabular}


表 9 つつきき

\begin{tabular}{|c|c|c|c|c|c|c|c|c|c|c|}
\hline $\begin{array}{l}\text { 症例 } \\
\text { No. }\end{array}$ & $\begin{array}{l}\text { 性 } \\
\text { 別 }\end{array}$ & $\begin{array}{l}\text { 受伤 } \\
\text { 年歯会 }\end{array}$ & $\begin{array}{l}\text { 受管 } \\
\text { ～初診 }\end{array}$ & 再来時 & 経過 & 受傷原因 & 打撲部位 & 骨折部位 & 整復法 & $\begin{array}{l}\text { 固定法 } \\
\text { その他 処置 }\end{array}$ \\
\hline 21 & $\mathbf{M}$ & 5 & 5 日 & 9 & 4 & 打撲 & 右顎下部～䫀部 & $\begin{array}{l}\overline{d c \mid} \text { 部 } \\
\text { 左下䫟角部 }\end{array}$ & 非観血的 & 曲縙結禁 \\
\hline 22 & $\mathbf{M}$ & 4 & 28日 & 8 & 4 & 交通事故 & 傾部 & $\begin{array}{l}\text { 正中部, } \overline{6} \text { 部 } \\
\text { 左顎関節突起部 }\end{array}$ & 観血的 & $\begin{array}{l}\text { 骨䋖合 } \\
\text { 囲繞結紮 }\end{array}$ \\
\hline 23 & M & 10 & 6 日 & 14 & 4 & 転倒 & 右下顎骨骨体部 & $\overline{7} \mid$ 部 & 非観血的 & 連続歯牙結热 \\
\hline 24 & $\mathbf{M}$ & 10 & 当日 & 13 & 3 & スポーッ & 願部～右骨体部 & $\begin{array}{l}\overline{54} \text { 部 } \\
\text { 左側额関節突起部 }\end{array}$ & 非観血的 & 2 歯結紮 \\
\hline 25 & $\mathbf{M}$ & 6 & 2 日 & 9 & 3 & 自車車事故 & 願部 & 左側買関節突起部 & 非観血的 & 連続齿牙結禁 \\
\hline 26 & M & 8 & 1 日 & 11 & 3 & 転倒 & 右隅角部 & $\overline{76}$ 部 & 観血的 & $\begin{array}{l}\text { 骨䋖合 } \\
\text { 囲繞結絷 }\end{array}$ \\
\hline 27 & $\mathbf{M}$ & 4 & 5 日 & 17 & 3 & 交通事故 & 左下顎骨骨体部 & $\begin{array}{l}\overline{32} \mid \text { 部, } \mid \overline{45} \text { 部 } \\
\text { 左側䫟関節突起部 }\end{array}$ & 観血的 & $\begin{array}{l}\text { 骨䋖合 } \\
\text { 連続歯牙結禁 }\end{array}$ \\
\hline 28 & $\mathbf{F}$ & 3 & 2 日 & 5 & 2 & 殴打 & 右願部 & $\begin{array}{l}\text { 正中部 } \\
\text { 左側顎関節突起部 }\end{array}$ & 非観血的 & 連続料牙結禁 \\
\hline 29 & $\mathbf{F}$ & $11 \mathrm{M}$ & 当日 & 3 & 2 & 欧打 & 頕部 & 正中部 & 非観血的 & 囲絖結禁 \\
\hline 30 & M & 5 & 2 日 & 6 & 1 & 自転車事故 & 頙部 & 左側顎関節突起部 & 非観血的 & 囲繞結紮 \\
\hline 31 & $\mathrm{M}$ & 8 & 2 日 & 9 & 1 & 交通事故 & 右顎下部～願部 & $\begin{array}{l}\overline{\mathrm{C} 2} \mid \text { 部 } \\
\text { 左上行枝部 }\end{array}$ & 非観血的 & 用繞結禁 \\
\hline 32 & $\mathbf{M}$ & 6 & 2 日 & 7 & 1 & 交通事故 & 右側煩部 & $\begin{array}{l}\overline{c b} \text { 部 } \\
\text { 左側顎関節突起部 }\end{array}$ & 非観血的 & 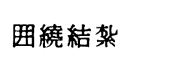 \\
\hline 33 & $\mathbf{M}$ & 5 & 4 日 & 6 & 1 & 交通事故 & 右願下部 & $\overline{6 \mathrm{E}}|,| \overline{\mathrm{DE}}$ 部 & 非観血的 & 囲繞結禁 \\
\hline
\end{tabular}

歯部が 3 線 (10.7\%)，下筫角部が 1 線 (3.6\%) で骨体 部骨折に打いて，永久歯歯胚のあるものは，多くはそれ を通るか，接していた。この年代は，犬雪小田雪部が多 く，正中部の頻度はかなり減少しており，犬歯小目部 が好発部位と推测された。

3) $8 \sim 14$ 歳

この年代は，26 例 43 骨折線で，犬歯小囦歯部が 19 線 (44.2\%) と半数近くを占めていた。次いで関節突起部 が12線(27.9\%), 正中部と大曰歯部が扣の扣の 4 線 $(9.3$ $\%)$, 上行枝部が 2 線 (4.7\%), 切歯部之下顎角部がおの おの 1 線 (2.3\%) であった。この年代では，犬雨小目 因部および顎関節突起部が好発部位と推測された。

\section{III. 治療法}

1.上顎骨骨折
陳旧例の 1 例は, ほとんど偏位むなかったため処置は 行われなかった. 他の 1 例は偏位骨切片の整復と脱落し た骨折片の再植術が行われた。

2. 下顎骨骨折

\section{1）下顎骨骨体骨折}

下顎骨骨体骨折51例中，整復固定が行われたものは42 例 $(82 \%)$ で，残り 9 例 (18\%) は，陳旧例や不完全骨 折で骨片の動摇や咬合異常がなく，消炎療法を行ったも のおよび顎の安静を計るため願帽を使ったもの各 1 例, 経過観察を行ったもの 7 例である. 整復法は観血的に行 ったもの16例，非観血的に行ったもの26例であった，受 傷より当科を受診するまでの期間および整復法との関 係を表 6 に示す．観血的整復法を行った16例中， 1 週間 以内の新鮮例は 9 例, 1 週間以上の陳旧例は 7 例であっ 


\begin{tabular}{|c|c|c|c|c|c|c|c|}
\hline 䚁覚 & 顔貌 & 開口 & 顎運動障害 & 骨折部粕牙所見 & 骨折部 X線所見 & 菌 列 & 合併症 \\
\hline- & 正常 & - & - & & & & \\
\hline - & 正常 & - & $\begin{array}{l}\text { 側方左右差 } \\
\text { 左へ十1 mm }\end{array}$ & | 1 崡根奇形 & & & $\begin{array}{l}\text { 左鎖骨骨折 } \\
\text { 左下肢打撲 }\end{array}$ \\
\hline- & 正常 & - & $\begin{array}{l}\text { 側方左右美 } \\
\text { 右へ+1 mm }\end{array}$ & & & & \\
\hline- & 正常 & - & $\begin{array}{l}\text { 側方左右差 } \\
\text { 左へ十3 m } \\
\text { 開口時患側へ偏位 }\end{array}$ & & & $\begin{array}{l}\frac{5 \mid 5}{15} \text { 舌側転位 } \\
\frac{1 \mid 1}{21} \text { は } 1 \mid 1 \text { より } \\
2 \mathrm{~mm} \text { 左へ }\end{array}$ & \\
\hline- & 正常 & - & $\begin{array}{l}\text { 側方左右差 } \\
\text { 左へ+3 mm }\end{array}$ & & & 下顎正中が右へ偏位 & \\
\hline- & 正常 & - & $\begin{array}{l}\text { 側方左右差 } \\
\text { 左へ+3 mm }\end{array}$ & & & 反対咬合 & \\
\hline- & 正常 & - & - & & & $\begin{array}{l}\overline{5} \mid \text { 唇側 やや傾斜 } \\
\mid \overline{5} \text { 舌側 }\end{array}$ & \\
\hline- & 正常 & - & - & & $\begin{array}{l}\text { 患側顎関節頭形 } \\
\text { 熊異常 } \\
\text { 罡正形の顎 } \\
\text { 䦳頭 }\end{array}$ & 下顎が若干左へ偏位 & \\
\hline- & 正常 & - & - & & & & \\
\hline- & 正常 & - & $\begin{array}{l}\text { 側方左右差 } \\
\text { 右へ+1 mm }\end{array}$ & & & & \\
\hline- & 正常 & - & - & & & $\overline{6 \mid 6}$ 近心傾科 & 意識消失 \\
\hline- & 正常 & - & - & & & $\overline{6 \mid 6}$ 近心傾斜 & $\begin{array}{l}\text { 第 } 1 \text { 中手骨骨折 } \\
\text { 意識消失 左滕関節 } \\
\text { 右大部 デン部打撲 }\end{array}$ \\
\hline- & 正常 & - & - & & & & \\
\hline
\end{tabular}

た。これに対し非観血的整復法を行った 26 例は全例が 1 週間以内の新鮮例であった。陳旧例の汪とんどは, 他部 合併症にて他の病院に入院していて遅くなったものであ るが, なかには外科, 歯科を受診しても骨折がわからず 湿布の及受けていた症例もあった。

固定法は表 7 のとおりで, 観血的整復を行った症例で は骨縫合が14例と最も多く,すべて他の固定法と併用し ていた。囲繞結紫法は 6 歳以下に多く, 線副子は 6 歳以 上に多くみられたが，骨縫合においてはとくに年齢差は みられなかった。非観血的整復を行った症例の固定法 は, 線副子を使ったものが最も多く15例, 次いで囲繞結 禁法の 7 例であった。

固定期間は, 観血的整復を行ったものが最短 14 日, 最 長42日, 平均26日, 非観血的整復を行ったものが, 最短
5 日, 最長34日, 平均19日であった。

2 ) 㴿関節突起部骨折

頜関節突起部骨折は20例（骨体骨折との重複症例も含 む）で，同部に関しては全例非観血的整復が採用され た。顎関節突起部骨折単独例は 8 例で, この内固定を行 ったものが 6 例であった．固定法は連続歯牙結紮法に て，固定あるいはゴム牽引をしたのが 4 例，連続歯牙結 禁法に頣帽を併用した症例が 1 例, 臨帽の及使用した症 例が 1 例であった。残りの 2 例は経過観察のみ，あるい は温湿布および開口練習のみの症例であった（表 8).

また，骨体骨折との合併例の固定法は表 7 のとおりで ある。

顎関節突起部骨折の及の症例に打ける固定期間は，平 均14日間であった。 
表 10 対象症例の骨折部位と整復法

\begin{tabular}{|c|c|c|c|c|c|}
\hline & & 骨体骨折 & 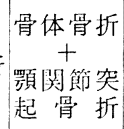 & $\begin{array}{l}\text { 顎関節突 } \\
\text { 起 悬 折 }\end{array}$ & 計 \\
\hline \multirow{2}{*}{$\begin{array}{l}\text { 整復処㨁 } \\
\text { 党行った } \\
\text { 米の }\end{array}$} & 覞 血 的 & 6 & 2 & 0 & 8 \\
\hline & 非钼血的 & 9 & 5 & 4 & 18 \\
\hline \multicolumn{2}{|c|}{$\begin{array}{l}\text { 整復処置を行わな } \\
\text { かったもの }\end{array}$} & 5 & 1 & 1 & 7 \\
\hline \multicolumn{2}{|c|}{ 計 } & 20 & 8 & 5 & 33 \\
\hline
\end{tabular}
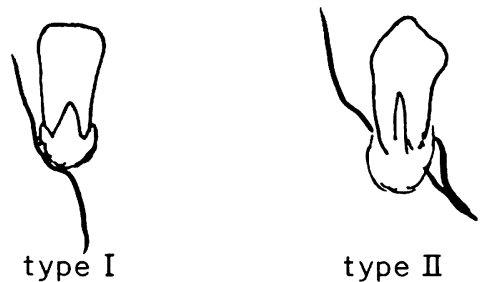

\section{type II}

-type I : 雨胚の下から入っているもの

•type II : 画胚の横から入つているもの

図 4 骨折線と幽㮟との関保

合併例での固定期間は，骨体骨折のみの症例と差はな かったが，単独例と比べると長くなっており，とくに骨 体骨折部の観血的整復を行った症例では約 2 倍になって いた。

\section{第 II 編 遠隔成績について}

\section{研 究 対 象}

1961年 1 月から1977年12月までの17年間に久留米大学 付属病院口腔外科を受診した15歳未満の下䫇骨”骨折（䛧 槽骨骨折単独例を除く）59例中，遠隔調查に応じた33例 を対象とした。その内訳は表 9 のとおりで，男性23例， 女性10例で, 経過年数は最短 9 力月, 最長 15 年 8 力月, 平均 6 年 1 か月であった。

なお，骨折部位については，顎関節突起部骨折の影管 をみるために，表10のよらに，骨体骨折の久，骨体骨折 之靧関節突起部骨折の重複，顎関節突起部骨折の灭の大 きく三つに分けて钼察した。

\section{研 究 方 法}

症例の分析には，受診後の外来および入院記録ならび にX線写真を用い，また遠隔調䍒においてては受診㭙の視 㡎，触䛦，X線写真，咬合模型を用いて次の項目につき

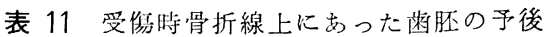

\begin{tabular}{|c|c|c|c|c|}
\hline \multirow{2}{*}{ 総 数 } & \multirow{2}{*}{$\begin{array}{l}\text { 処置時 } \\
\text { 抜 将 }\end{array}$} & \multicolumn{3}{|c|}{ 再来時の状態 } \\
\hline & & $\begin{array}{l}\text { 邺根 } \\
\text { 形成中 }\end{array}$ & 正常萌出 & $\begin{array}{l}\text { 崡根形態 } \\
\text { 異 }\end{array}$ \\
\hline 28 & 1 & 7 & 14 & 6 \\
\hline
\end{tabular}

表 12 苯根形態異常の分類

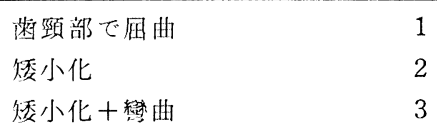

6 (2)

（）内は䛧冠部石灰化不全を伴っているもの

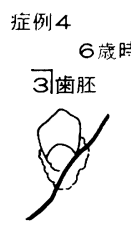

受䇚時

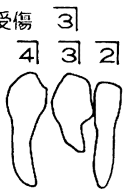

再来時

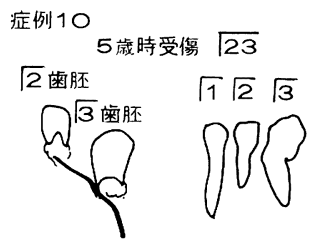

受豌時
再来時
症例 12

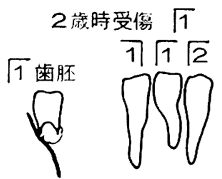

受復時
症例 16

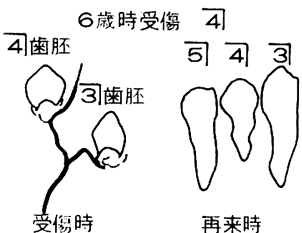

症例 22

$$
4 \text { 藏時受伤 } \sqrt{1}
$$

厂菌胚 $\quad$ 1 $\sqrt{1} \sqrt{2}$

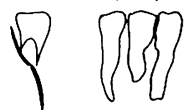

受衡時

図 5 骨折線と永久咐附根の形態異掌

調查した。

I 。骨折部における略怀，米牙の所見

II . 嵝列および咬合の所見

III. 顎関節突起部骨折の所見

1. 顔貌所見

2. 顎運動所見

3. X線学的所見

X線写真としては, 後䫓一前頭位报影, パノラマX線

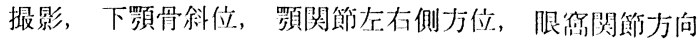


表 13 処置と迷根奇刓

\begin{tabular}{|c|c|c|c|}
\hline & 観血的処置 & 非钼血的処置 & 計 \\
\hline 正 常 & 2 & 12 & 14 \\
\hline 奇 形 & 4 & 2 & 6 \\
\hline 計 & 6 & 14 & 20 \\
\hline
\end{tabular}

表 14 瞍根の数と予後

\begin{tabular}{c|c|c|c}
\hline & 単 根 & 䙎 根 & 計 \\
\hline \begin{tabular}{c|c|c} 
正 常 \\
奇 形
\end{tabular} & 9 & 5 & 14 \\
\hline 計 & 15 & 0 & 6 \\
\hline
\end{tabular}

表 15 受俱時檤肧の形成時期と予後

\begin{tabular}{c|c|c|c}
\hline & 荈冠形成完了以前 & 麥根形成中 & 計 \\
\hline 正 常 & 6 & 8 & 14 \\
奇 形 & 5 & 1 & 6 \\
\hline 計 & 11 & 9 & 20 \\
\hline
\end{tabular}

表 16 骨折線の type と菌根奇形

\begin{tabular}{|c|c|c|c|}
\hline & I & II & 計 \\
\hline 正 常 & 9 & 5 & 14 \\
\hline 奇 形 & 6 & 0 & 6 \\
\hline 計 & 15 & 5 & 20 \\
\hline
\end{tabular}

表 17 骨折部位と咬合および鄫列

\begin{tabular}{|c|c|c|c|c|c|c|c|}
\hline & 正常咬合 & 反対咬合 & 切端咬合 & 上顎前突 & $\begin{array}{l}\text { 涌の捻転 } \\
\text { 傾斜・転位 }\end{array}$ & $\begin{array}{l}\text { 下顎正中 } \\
\text { の偏 位 }\end{array}$ & 計 \\
\hline 骨体骨折 & 9 & 2 & 0 & 1 & 7 & 1 & 20 \\
\hline 骨体骨折＋顎関節突起骨折 & 3 & 0 & 1 & 0 & 3 & 1 & 8 \\
\hline 顎関節突起骨折 & 1 & 0 & 0 & 0 & 2 & 2 & 5 \\
\hline 計 & 13 & 2 & 1 & 1 & 12 & 4 & 33 \\
\hline
\end{tabular}

表 18 䫇関節頭形態異常の有無と骨折型

\begin{tabular}{|c|c|c|c|c|c|c|c|c|c|c|}
\hline & & \multicolumn{2}{|c|}{ 転位なし } & \multicolumn{2}{|c|}{ 偏位骨折 } & \multicolumn{2}{|c|}{ 転位骨折 } & \multicolumn{2}{|c|}{ 脱臼骨折 } & \multirow{2}{*}{ 計 } \\
\hline & & 低 位 & 高 位 & 低 位 & 高 位 & 低 位 & 高 位 & 低 位 & 高 位 & \\
\hline \multicolumn{2}{|c|}{ 正 常 } & 2 & 0 & 2 & 0 & 0 & 1 & 1 & 5 & 11 \\
\hline 異常 & $\begin{array}{l}\text { 八ート型扰よび凹凸不整 } \\
\text { 二股様 }\end{array}$ & $\begin{array}{l}0 \\
0\end{array}$ & $\begin{array}{l}0 \\
0\end{array}$ & $\begin{array}{l}2 \\
0\end{array}$ & $\begin{array}{l}0 \\
0\end{array}$ & $\begin{array}{l}0 \\
0\end{array}$ & $\begin{array}{l}0 \\
0\end{array}$ & $\begin{array}{l}0 \\
1\end{array}$ & $\begin{array}{l}0 \\
0\end{array}$ & $\begin{array}{l}2 \\
1\end{array}$ \\
\hline & 計 & & 2 & & 4 & & 1 & \multicolumn{2}{|c|}{7} & 14 \\
\hline
\end{tabular}

位，咬合法，口内撮影法ならびに靧顔面規格写真を用い 検討した。顎運動については，視診にて安静咬合時の正 中線を決定し，それを基準に開口時の運動状態をもって 判定した.

なお，骨折線と歯胚との関係は図 4 のごとく，Type I と Type II に分けて観察した。

すなわち Type I は，骨折線が下から入っているも の, Type II は骨折線が横から入っているものとした，

\section{研 究 成 績}

\section{I ，骨折部における歯胚，歯牙の所見}

骨体骨折のある28例中受傷時に骨折線上に歯胚があっ
たのは，28歯で処置時抜歯した画肧は1䊝であった，再 来時に正常形態で萌出していたものは14歯，まだ未萌出 で䄳根形成中のものが 7 畨, 齿根に形態異常を呈してい たものが 6 米にみられた（表11）。歯根形態異常の内訳 は，歯頸部で屈曲していたもの 1 歯，矮小化していたも の 2 歯, 彎曲を伴って矮小化していたもの 3 歯であった （表12, 図 5)。 5ち2 歯は，視診にて歯冠部石灰化不全 を認めた。

崊根形成が終了している20粦について, 根奇形と処置 との関係をみると，表13のごとく，観血的に行ったもの が 6 㐘中 4 蔽の $66 \%$ と観血的処置を行ったものに多く又 られた。㐘根の数との関係は表14のごとく，全例単根画 であった，受傷時蒾肧の形成時期との関係は表15のごと 

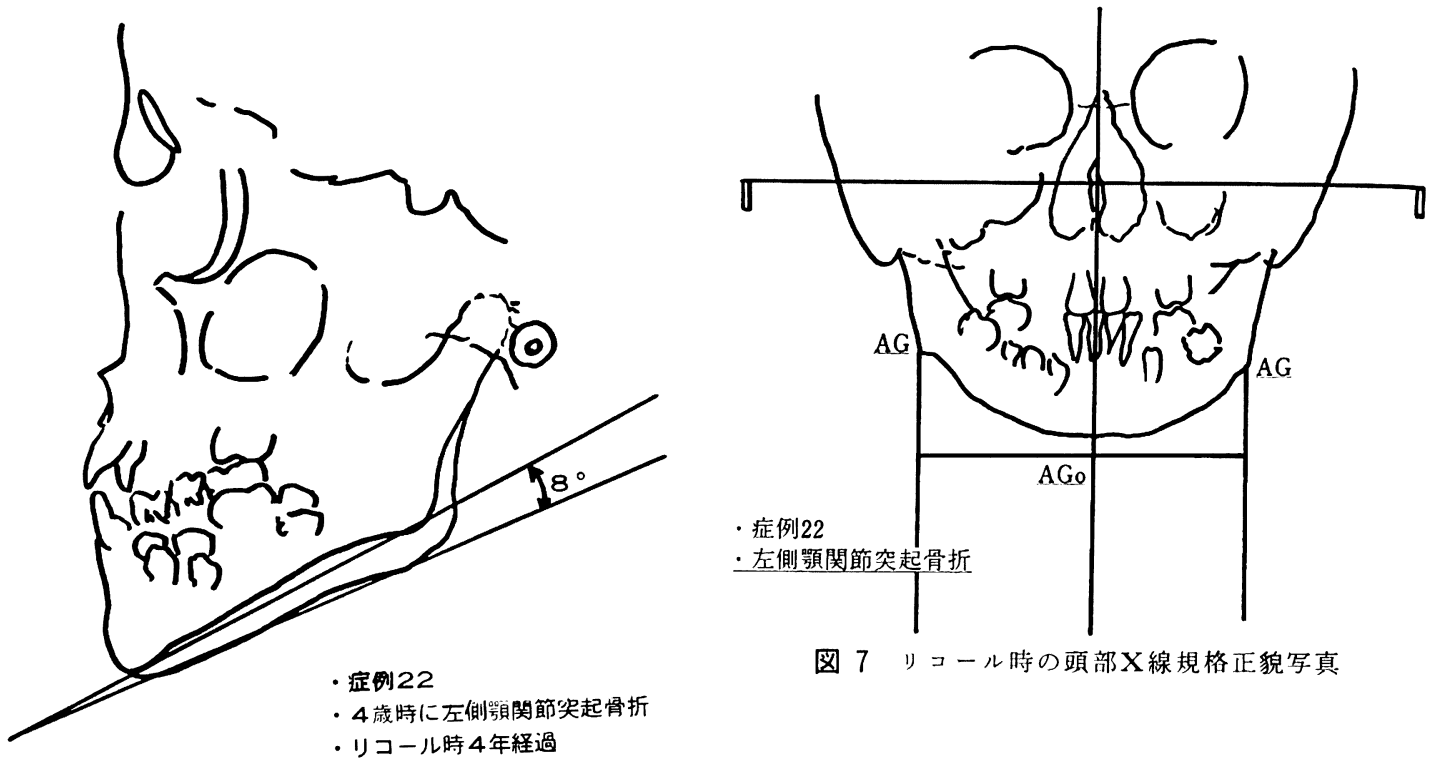

図 7 リコール時の頭部 $\mathrm{X}$ 線規格正貌写真

図 6 リコール時の頭部X線規格側貌写真

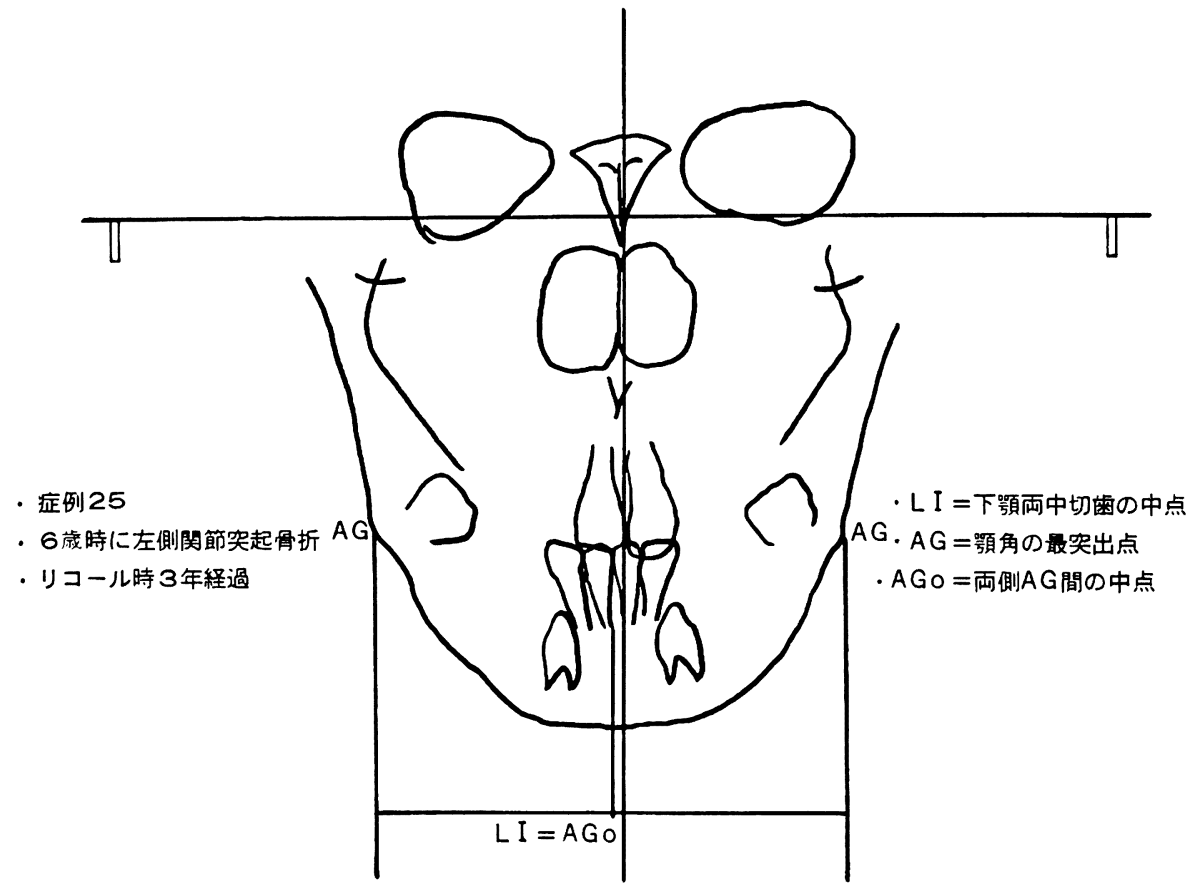

図 8 リコール時の頭部X線規格正貌写真

く歯冠形成完了以前が 11 幽中 5 歯 $45.4 \%$ ，歯根形成中 のもので 9 歯中 1 歯 $11 \%$, 歯冠形成完了以前のものに 多くみられた。骨折線との関係は，表 16 のごとく全例 Type I であった。

\section{II ．歯列および咬合の所見}

料列や咬合の所見は，正常咬合13例，反対峧合 2 例, 切端咬合, 上䫇前突各 1 例, 萪牙の揄転, 傾斜, 枟位 12 例，下顎正中の偏位 4 例であった（表17）。 

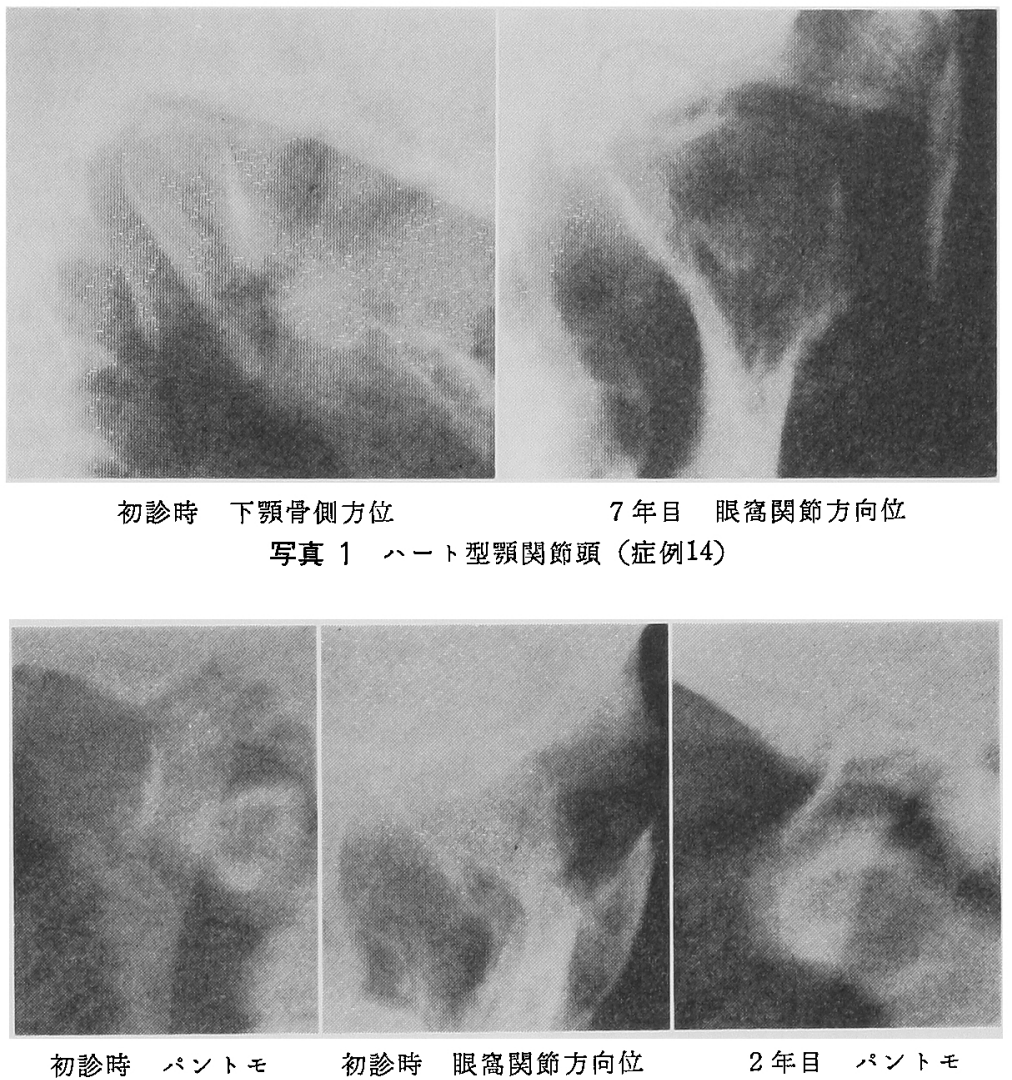

写真 2 凹凸不正形の顎関節頭（症例28）
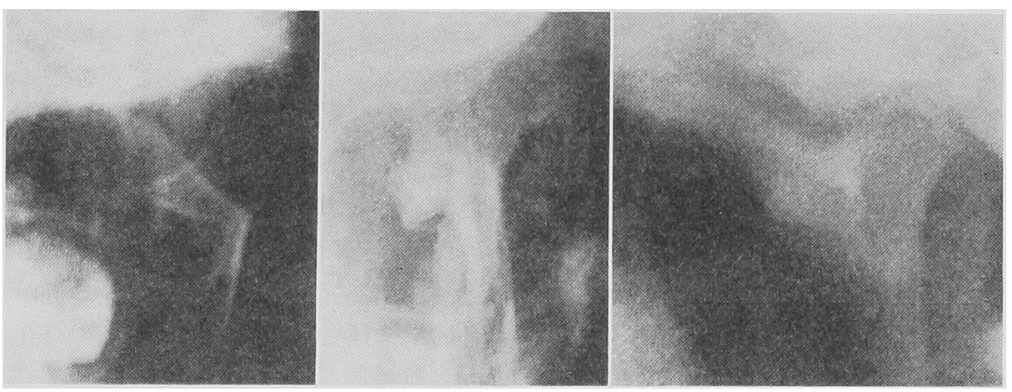

初診時 前頭後頭位 5 年 7 か月 眼蛧関節方向位 パントモ

写真 3 二股様形態の顎関節頭（症例 7)

筲折と関係があると思われるものは，歯根の屈曲によ り歯冠が遠心傾斜したもの 1 例，処置時の歯肧拔去に より後方歯牙が近心移動したもの 1 例，片側顎関節突起 部骨折による㴿の発育異常で下䝷正中が健側へ偏位した と思われるるの1例で，他は骨折との関係は認められな かった.

\section{III. 䪽関節突起部骨折の所見}

今回の調查に応じた症例中，買関節突起部骨折を有し ていたのは片側12例, 两側 1 例の計13例で, MacLennan
の分類では，転位なし 2 例，偏位骨折 4 例，転位骨折 1 例，脱臼骨折 7 例であった。 また，高位骨折 6 例，低位 骨折 8 例であった (表18).

1. 顔貌所見

須関節突起部骨折症例において，下須骨成長の中心が 下顎頭にあるとされており，受傷後の下䫇骨の成長に障 害がでる可能性があるとされている．今回の予後調查に 応でた13症例に执いては，視診に和ける顔貌所見に変形 は認められなかったが，顎颜面規格写真正面像に扣いて 


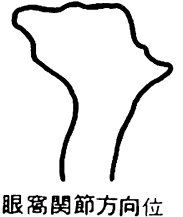

症例13

パノラマ

症例 27

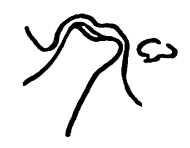

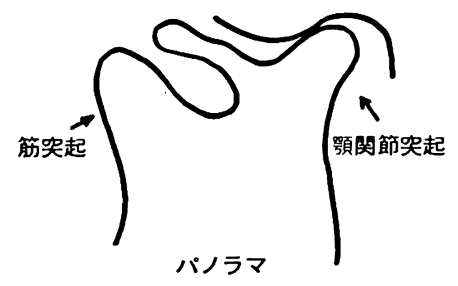

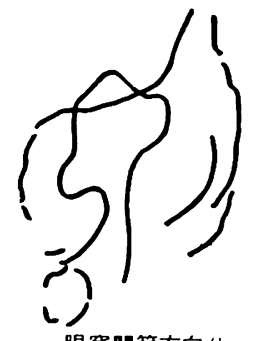

症例 16
図 9 顎関節頭形態異常

は，片側性の脱臼骨折の 2 症例において健側へ，また 1 例に患側への偏位が認められた（図 6〜8).

2. 顎運動所見

顎運動においては, 開口度は全例 $40 \mathrm{~mm}$ 以上で, 片 側関節突起骨折の 2 症例に, 開口時患側への偏位が認め られた。側方運動においては, 骨体骨折のみの 3 例, 関 節突起骨折を有するもの 7 例に, $1 \mathrm{~mm}$ 以上の左右差が 認められ，その他の症例ではほぼ同等であった。顎関節 部の䫍運動時の疼痛, 雑音は認めなかった。 また, 固定 法や固定期間による差も認められなかった。

\section{X線写真所見}

受傷時の骨折型, 子後調查時の経過年数はさまざまで あるが, 全例非観血的整復法を行っている. 尒後調査時 の下顎頭部の形態は，3例を除くと, 骨折型や固定法, 固定期間に関係なくほぼ正常の形態に復していた。形態 異常を呈した 3 例は, 骨折型が低位偏位型が 2 例で, 万 ち 1 例は八ート型（写真 1)，1 例は凹凸不正形（写真 2 ）を呈していた。他の 1 例は低位脱臼型で残遗小骨片 と新生下顎頭が融合した二股様形態（写真了）を呈して いた(表18，図9）。しかし，これらが低位骨折であり， 二股様形態を呈したもので固定期間が長かった以外，と くに要因は認められなかった。またこれら3 例も， 1 例に開口時患側への偏位を認める以外に機能障害は認め られなかった。
考

察

\section{1）臨床的観察について}

小児の顎骨骨折の頻度についてみると，本統計におい ては全顎骨骨折患者数の $14.5 \%$ であり, 従来の報告に比 べて大差はみられなかった6,8,9,16 23)

性別についてみると，男女比は2.8:1（男児 73.3\%） で男児に多くみられ，いずれの報告でも若干の差はある が男児に多かった。これは，本調査に打ける受傷原因か らも推察されるが，男児と女児の行動性の違いによるも のと考学る $2,3,7 \sim 9,17,20,24 \sim 26)$.

受傷原因として，清水 ${ }^{27)}, \mathrm{McCoy} ら$, 清田 ${ }^{16)}$, および 本調查に打いては交通事故が最も多く, Shira や Hall は 転落が, Morgan ${ }^{25)}$ は自転車によるものが最も多かった と述べている。それらの年代および地域による生活環境 や交通事情があり比較検討することは困難であるが，最 近の報告では多くが交通事故, 転落, 自転車事故が上位 を占めていた，本調查においては，自動車事故が最も多

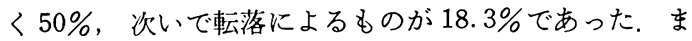
た，転落を除き他の原因のほとんどが男女比2: 1〜3:1 と男児に多く，転落にいたっては全例が男児であり，男 女の行動様式の違いが表れているものと思われる.

骨折部位についてみると好発部位は報告者により多少 違いがあるが，いずれも前歯部と顎関節突起部とされて おり9,17,24 26)，わたくしの成績でもそうである. その理 由として，前雨部についてはFreid と Baden ${ }^{1)}$ や渡辺 ら²)が函胚が密集しているために骨折しやすいと述べ, 顎関節突起部については，金田 ${ }^{28)}$ が実験的に，下顎骨が 願部に垂直圧縮荷重を受けた場合，下顎頸部では曲げ応 力, 王縮力とも最大となることを示している.わたくし の成績でも，直達，介達と別けてみると直達では前采部 に多く，顎関節突起部骨折はほとんどが介達であったこ とより金田の実験結果と一致している。その上，とくに 䫇関節突起部では細いため介達骨折が多いと考える.

清田は好発部位が永久霜雨胚の存在とその発育扰よび 顎骨の発育と関係があると考之, 3 つの年柃層（ $0 \sim 3$, $4 \sim 7,8 \sim 14$ 藏）に分けて検討している. その結果 4

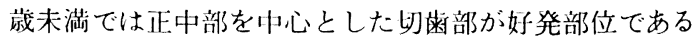
とし，4〜7歲では犬米小罒部が好発部位であると し，8〜14藏でも犬画小臼崡部に最も多く, 顎関節突起 部も增㞦している述べている。

わたくしも同様の考えのトにまた清四の報告と比較 するために同年秢層に分けて検封してみた。 その結果, 4 藏末湍では清田と同じく正中部を中心とした切蒌部に 多く70\%を占め，䫚関節突起部が30\%であった，4〜7 藏では犬歯小目幽が32.1\%で最も多く，次いで正中部を 中心とした切函部の $28.6 \%$ ，罘関節突起部は25\%であっ た. 8 14藏では，やはり犬料小目曾部が $45.2 \%$ と最も 
多く, 次いで顎関節突起部の $26.2 \%$ であり，正中部を中 心とした切秚部は $11.9 \%$ に減少していた。 4 歳未満で切 歯部に多くみられたのは, 永久切将蔽胚が大きくなって きており密に存在しているためと思われ，4〜 7 嵅で犬 歯小田歯部に多いのは，切蔽部では歯牙が交换中あるい は終了しており，犬雪小四幽雪胚が大きくなっているた めと思われる． 8〜14歳でも犬歯小目歯部に多くみら れ，これは犬歯小臼歯がまだ乳菌と交換中であり，顎骨 が彎曲している部分であることから外力の影響を受けや すいものと思われる。 また，全年路層を通じ，顎関節突 起部については清田の報告と比べて高頻度で年齢層間で の差は認められなかった。これは，顎関節突起部が年齢 に関係なく外力による応力が集中しやすい場所であり， 頸部が形態的に細長いためと考える。

小児顎骨骨折に打ける他部合併損傷についての報告は 少ないが16,17,25,26)，それらをみると頭部外傷が最も多い ようである。しかし，頻度は少なくなるが全身的に合併 症がみられる。そしてそれらの受傷原因としては，交通 事故や転落等全身的に打掽を受けやすく外傷力の強い事 故に多くみられる。当科に打恰る合併症は小児顎骨骨折 患者の $38 \%$ にみられ, 頭部外傷が最も多く, 腹部を除く すべての部位にみられた。それらの受傷原因中，交通事 故が59\%を占め, 次いで転落が $28 \%$ であり, 外伤の受け 方や外傷力の大きさによるものと考える。

治療法についてみると, 骨体部骨折では骨折部位や骨 折の状態, 歯牙歯列の状態, 治療時期によって治療法が 異なると思われるが，基本的には外賃による侵襲にさら に手術による侵襲を加えることをできるだけ避けるこ と, 永久歯歯胚への障害を避けること, また手術が簡便 で患児の協力を得やすいことが必要である。手技の簡便 さから連続歯牙結禁法や他の金属副子を使った固定法が よく使われるが，それらの方法によるとウ蝕菡や欠損荬 が多い場合や歯牙の交換期で乳歯が動摇していたり永久 歯の萌出が不完全な場合には固定力が不十分である。 た，固定期間中に㴿間固定が必要で患者自身不自由であ り，長期間顎間固定を行うと固定除去後に開口障害を生 じることから、それらを解決し得る囲繞結柴法を推奨す る術者が多(、3,6,29 31,48)

筆者らも固定時や固定装置除去時に全身㑣酔を要する ことを除けば，先の理由により多くの症例に囲絔結禁法 を行い，治療中や子後に良好な結果を得ている。しか し, 固定源としての蒾牙粦列がしっかりとしてい机ば, 来院時にすぐ局所麻醉のみで簡便にできることから, 連 続齿牙絬柴法や金属副子を使用することも多く，顎間固 定除去後しばらく開口制限を有する症例もあるが予後は 良好である。なお，本症例中に骨縫合を行ったものが数 例あるが，X線写真的に鋼線は永久料歯胚から離れてお

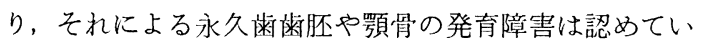
ない。しかし, 尒後調査に打いて骨折線上の㴹牙の異常
が，钼血的整復例に多いことは再考を要するものと考え る。

罘関節突起骨折の治㙩法に関しては，Wolff's law で もいわれているよらに，発育期の骨が骨折しても，それ 自体で再形成する力を持っていること，また観血的な手 術を行った場合には，その手術自体が外傷となり下靧頭 部にある growth center を損傷し，障害を生ずる危険性 もあることから， ほとんど保存的処置が行われている。 Rakower ${ }^{32)}$ ら, Thomson ${ }^{11)}$ ら, MacLennan ${ }^{12)} と$ Simpson, Leake ${ }^{13)}$ らは保存療法にて良好な結果を得たと述 ベ, Halli), 清田, 西嶋ら ${ }^{9)}$, Adekey ${ }^{17)}$ らは, 後遗症と して䋶関節強直症や顔貌の非対称性, 開口時の顎の偏位 等を認めているものの多くは良好な結果を得ており保存 的療法を推奨している。 しかし, Kaplan と Mark $^{33)}$ p McCoy ら, Hoopes ${ }^{34)}$ らは原則的には保存療法である が，極端な重症例には観血的手術が必要であるとしてい る. また Becker と Sheridan ${ }^{35)}$ は粉砕した下顎頭の骨 折片を摘出した症例を報告し, 術後 4 か月には機能的に 異常はなかったとしているが，その後の観察については 触れていない.

われわれの症例中顎関節突起部骨折は20例で, 全く処 置しなかった症例が 1 例, 理学療法および開口練習のみ 2 例, 弾力包带あるいは願帽の及 3 例, 最も多く行った のが連続歯牙結紧法の10例, その他 4 例で, 顎関節突起 部骨折のみの 8 症例では, 整復処置を必要としなかった 2 例を除きほとんど連続歯牙結紮法を用いてゴム牽引を 行っており，そのうち1例のみに鋼線による5 日間の䫇 間固定を行っている. Kaplan や Leak, Adekey らは頭 関節の機能的，形態的障害を防ぐには早期に顎運動をさ せる必要があると述べ，清田は咬合異常がある場合には ゴム㒕引にて整復し，その後一定期間咬合保定のために 顎間固定が必要であると述べているが，骨折部の骨性 癒合をはかる意味での䫇間固定は否定している。また Wolff's law は骨がストレスや機能に適合するように形 態を変える傾向があるとし，われわれの症例でも下顎頭 が骨の吸収添加により正常な位置および形態に復してい く所見を得ており，この法則に従ったものと思われる。 このことから，わたくしも骨性癒合をはかるための䫟間 固定は行らべきではなく，骨体部骨折等の合併骨折があ る場合にも長期間の固定が必要であれば囲絖結紫法を行 ったり，症例によっては骨縫合も併用して骨折部の安静 をはかり早期に顎運動を行わせるべきであると考え，ま たそのように行ってきてなんら障害を認めていないこと から, 顎関節突起骨折の治療に関しては今までの治療法 で正しかったと考える。

なお，小児顎骨骨折において骨縫合はさけるべきだと の意見があるが，York ${ }^{36)}$ は生後 3 週目の乳児に骨縫合 を行い, Kaplan は症例により骨縫合も必要としてい る。おたくしも骨体部骨折に行った症例で，骨縫合によ 
る顎骨や永久歯米胚への発育障害は認めて招らず，永久 歯歯胚をさければ絶対的禁忌とは考えていない。

2）小児顎骨骨折の遠隔成績について

遠隔成績で最も大切なことは，対象症例のうち，何例 が調査に応じなかといらことで, 全例調査に応しててくれ ることが望ましいわけである。

しかし，小児骨折症例では顎骨発育途中では，明解な 結論は出しにくく䫇骨の発育停止時の調査が望ましい が，それたけ経過期間も長くなり, 調查が非常に困難と なる.

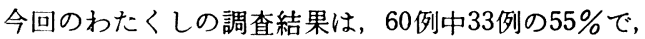
経過期間は最短 9 か月, 最高 15 年 8 か月（平均 6 年 1 か 月）であった。これを本邦での予後調査を行った清田， 西嶋らと比較すると清田は106例中17例 (16\%), 最短 1 年より最長 6 年 6 か月（平均 3 年 6 か月）で，西嶋らは 52 例中 17 例 $(32.6 \%)$, 最短 11 か月より最長 8 年 2 か月 （平均 3 年）で, いずれもわたくしの成績より低く短い.

一方外国の例でみると，Ranta と YLipaavalniemi ${ }^{38)}$ は43例中25例 $(58 \%$ ) 最短 4 年から13年 (平均 10 年), Leake らは 20 例中13例 $(65 \%)$ 最短 2 か月から 17 年, 3 年以上では20例中 6 例 $(30 \%)$, Thomson らは㖽関節 突起骨折の及の症例で52例中 23 例 (44\%) 最短 2 年以上 で平均 4 年 6 か月といずれも高い調査率を示している.

䫇骨骨折が骨折線上の 永久崡茵胚へ及ぼす影響とし $\tau$, Hall, Lenstrup ${ }^{37)}$, Ranta $と$ Y Lipaava Inieme, Larsen ${ }^{39)}$ と Nielsen, 清田, 西嶋らは歯冠および函根 の形態異常, エナメル質形成不全, 埋伏歯, 歯牙腫, 幽 髄腔の消失等を報告している。笹野 ${ }^{400}$ は子犬を使った実 験で, 外傷が醉胚の細胞配列に破壊扰よび変性を起こし 奇形歯や雪牙腫を生ずると述べている. Lenstrup は外 傷による永久雨幽泼の偏位が彎曲米, 埋伏ならびに萌出 位置の異常につながるとしている。また，Rantaは歯牙 の形成異常の要因として受傷時の歯牙形成時期によると し，受傷時にすでに雨根形成期に入っていたものは正常 に萌出し，まだ四冠の石灰化期にあるものに著しい米冠 および雪根の形態異常がみられたと述べている。一方清 田は観血的整復例に異常が認められたことから，手術侵 竩も障害の一因ではないかと述べている。事実, わたく しの結果でも形態異常を認めたものは 6 歯で, 矮小化し た彎曲米根 3 歯, 矮小米根 2 歯, 歯頸部で「く」の字に 屈曲したもの 1 米で, そのうち 2 米は霜冠部石灰化不全 を伴っていた，受聚時の歯胚形成時期をみると 6 粦中 5 崡が歯冠形成完了以前で， 1 雨が歯根形成期に入ってい ると思われ，ほとんどが歯冠形成期にあり Ranta の説 を裏付けていた。ささらに，骨折線上の歯牙はすべてかと いらとそらではなく形態異常あるいは萌出異常を呈した ものは 26 本中 6 歯で, 骨折線の歯胚を通る位置に関係 があるように思われ，骨折線の方向と歯胚との関係を Type I, II と分けてみたら, 全例陱泼の下から入り侧面
に拔ける骨折線が通る Type I に属した。ままた彎曲菡根 に执いては骨折線の方向と彎曲が柴頸部から始まる方向 が 3 例とも一致していた。雪根の数との関係では全例単 根歯にみられ，複根雬にはみられなかった。これは受傷 時に歯胚へ養分を供給する血管が切断されたかどらかが 関係しているものと考える。骨折部の処置との関係で は, 非観血的処置を行った症例では奇形雨は正常歯の 1/6で，観血的処置を行った症例では奇形歯が正常歯の 2 倍になっていた．また，観血的処置を行った 4 例中 2 例は骨折部の骨離断や搔爬を行っていた，以上のことよ り, 歯根の奇形は外傷や手術侵襲によって歯冠形成期の 雨胚の細胞が傷害されることによって生じると思われ， また全例単根歯で複根歯にみられなかったことは, Ranta の報告にもあるよらに，歯泼への栄責供給障害 が関与していることが推察された。 また, 形態異常はな いが骨折線上にあった歯胚たけが捻転して萌出していた 症例もみられ，これは䨑胚の偏位によるとする Lenstrup の考えに相当するものと考えている。 しかし，報告され ている歯牙腫, 歯髄腔の消失をみたものはなく, 埋伏菌 も今回の成績ではみられなかった。

䫇骨骨折により骨折線上の歯牙が久損した場合等に歯 列や咬合異常, 頡の発有異常が生じることも報告されて いる.

Hall は骨折により歯牙が 欠損した場合に隣接した歯 牙や対向雪に萌出異常をきたし，咬合異常を生じると述 べ，それも切雨部の歯牙欠損により生じやすいと述べて いる．清田は，骨折時に 2 本の乳前雨を欠損し後続永久 幽が萌出しなかったため $\overline{321 \mid 3}$ の近心傾斜をきたした と報告している，われわれの症例でも，骨折時に可の 歯泼を欠損したために $\overline{54}$ の近心傾斜をきたした症例が 1 例認められた。 また，骨折線上の米牙のみ捻転してい る症例もみられ，受傷時に柬牙あるいは米胚が捻転した ものと推測される。

Lewars ${ }^{41)}$ は骨体部骨折に扣いて異常答合したり骨が 欠損すると咬合異常を生じると報告している。

顎関節突起部骨折による咬合異常として，MacGregor $^{10)}$ と Fordyce は13例中 2 例に Angle II 級がみられ, Thomson 5も23例中 4 例に交叉咬合が，1 例に開咬が みられたと述べている。清田は20例中 5 例に咬合異常を 認め, そのらち交义咬合の 1 例と切端咬合の 1 例に骨折 による影響を疑っている。わたくしが調査した 33 症例 中（内，関節突起部骨折のあるもの13例） 4 例（同 1 例） に咬合異常を認めたが、いずれも受傷前からの咬合異常 であったり，受傷前の咬合状態がはっきりしないもので 骨折との関係を断定するには到らなかった。

いずれにしても，受傷により多数歯欠損や骨折部の異 常嘴合あるいは顎関節突起部骨折による強度の顎骨発育 異常がなけば、いわゆる機能正常咬合に落ちつき得る と考えている。 
頭骨の発有異常について，MacGregor は13例中粉磁 骨折たった 1 例に患側の軽度の顎骨発有抑制扣よびわず かな顔貌の変形を報告し，Larsen らは 16 例中 1 例に患 側の過剩発育による下顎正中の健側への偏位を認め，あ と 1 例には患側関節突起の形成不全を認めるも審美障害 はなかったと述べている，清田は，顎骨の発育抑制ある いは過剩発育により顔貌に非対称性を生した 2 症例を報 告している。亩た，西嶋らは 6 例中 1 例に軽度の顔貌の 非対称性を認めている。.Adekey は12例中 2 例に顎関節 強直症を伴った患側の㴿発育抑制を報告している。しか し, MacLennan と Simpson は関節突起部骨折を保存的 に治療した 6 症例について述べ，すべて顎骨の発育障害 はなかったと述べている，Rakower らや Leake らも予 後良好であったと報告している，䫇関節突起部骨折の後 遺症としては, 一般に靧運動障害，とくに開閉口時の䫇 の偏位, 開口障害, 関節雑音であるが，小児では下顎骨 の growth center が下顎頭に存在するため外傷による顎 骨の発育異常が問題となる。事実，下顎頭損傷による実 験でも明らかである。すなわち，久保田 ${ }^{42}$ は生後約 3 か 月の幼若犬に下罘頭の切除や下顎窩搔爬等の外傷を加光 た実験で, 手術側の顎骨発育不全を認め growth center のある下㴿頭の重要性を示している。 Lovasko と La$\operatorname{skin}^{43)}$ は 6 ～10か月のきつねザルを使い，1つのグルー プは下顎頭を切除し，もう1つのグループは下罘頭を除 去した後に人工の下靧頭を取りつけた実験を行いどち らのグループも下顎頭の再生を認めたものの患側の発育 が抑制されたと報告している。

X線学的に頂顔面骨の非対称性をみる場合, 頭部X線 規格正貌写真でも正中線を，とくに下䫝骨の正中を決定 する方法はないようである。しかし，下顝骨を除く顔面

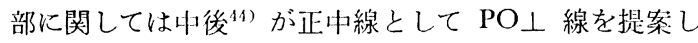
ている。この $\mathrm{PO} \perp$ 線と, 下買では左右中切翻中点 と両側下顎角最突出点の中点を正中として考えた場合, 2 例に下顎骨の健側への軽度の偏位が認められ過剩発有 が起っているものと推察された。 また，1例に下顎骨の 患側への軽度の偏位が認められ，これは頭部 X 線規格 側貌写真にても患側の発有が抑制されたと推察された。

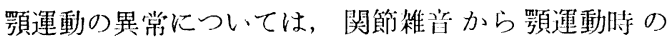
偏位あるいは顎関節強直症むで種々報告されている。 Adekey は顎関節突起部骨折に保存療法を行い, 12 例中 6 例に頢関節強直症を生じていたが，これら6例はすべ て受賃後 6 か月以上経った陳旧例で，それを尒防与る意 味でも早期治療が必要であると述べている. Blevins

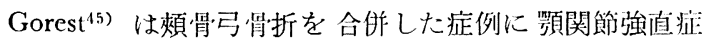
を認めて扣り，これは固定期間が 8 週間と長く，固定除 去後開口障害があるも食事にさしつかえないため, 甘親 が固定除去後の治療に従わなかったもので，また，合併 した煩骨弓骨折の過剩な仮骨形成が原因としている。 Hall は靧関節強直症の 1 例と再発性亚脱㑑を起こす 1
例および関節倠音を認める1例を報告している，Thomson は23例中開口時の偏位を15例に, 関節倠音を 1 例に 認めているが，運動量の制限はなかったと報告してい る. MacGregor は13例中 2 例に開口時の偏位を認め, 清田は 9 例中側方運動に 1 3 mm の左右差があったも の 7 例と開口時の偏位が認められたもの 5 例を報告して いる。 また，西嶋らは関節突起骨折例 6 例中 2 例に開口 時偏位を認めている。野 ${ }^{46)}$ は顎関節疾患に関する研究 で，顎関節強直症患者の中に小見期の外傷が原因である 症例を記載しているが詳細は不明である。 Leake らや Larsen と Nielsen ${ }^{39)}$ は, 症例中に運動障害を認めてい ないわたくしの症例では, 13 例中開口域は全例 40〜 $62 \mathrm{~mm}$ で開口障害は認められなかったが，片側脱臼骨 折のあった 2 症例に開口時に $6 \sim 9 \mathrm{~mm}$ の患側への偏位 が認められた。 また，側方運動において 7 例に 1〜 $4 \mathrm{~mm}$ の左右差が認められ，内 4 例が患側へ， 3 例が健側へ強 く動いていた。これらについて固定期間や経過年数との 関係は認められなかったが， 7 例中 5 例は脱臼骨折であ った。 また，健側への動きが大きかった 3 例中 1 例は頧 骨の過剩発育が推察された症例である。顎運動中に患側 の下顎頭を触知し得なかった症例も 1 例にみられた。こ

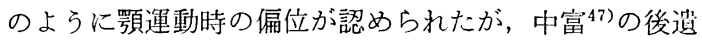
症の分類では全例完全治癒であった。

小児の顎関節突起部骨折において，将来買骨の発育異 常が機能障害を生ずることが問題であり，それは下䪹頭 にある growth center が関与していることが知られてい る. MacLennan は関節突起部骨折による永久的な発有 障害は 5 藏未満の小児に起こりやすく，5藏以上の小罢 では減少すると述べ，Rowe ${ }^{5)}$ は文献に 3 藏未満の関節突 起部骨折症例では積極的に機能させないと買関節強直症 を起こしやすいと述べている，Wolff’s law は骨にスト レスや機能に適合するよら自己修復する傾向があるとし ている。わたくしも正常な顎骨の形態や機能を得るには 䫇関節突起の正常な修復治癒が必要で, そのためには早 期より正常に機能するよら訓練すべきで，䪽関節突起と 䫇骨の機能および形態ならびに吹合との間には密接な関 係があると考える。また，わたくしの症例に強い後遺症 がなかったのも早期より正常に機能するよう訓練したた めと推察する。

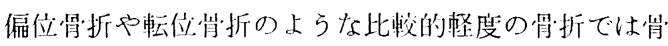
の吸収添加により修復されるが7,8,41)，これはWolff's lawとも一致している。わたくしも症例中に同様の所見 を認め，これに賛同与るものである。一方，脱四骨折 に関しては骨折した関節突起は吸収消失し，一枵頁枝の骨 折端より新しい関節突起が形成されると報告されてい る8,13,44,47) また，Lovasko43) はきつねザルを使った垁 鈳で, 関節突起を除去した後, 下䫵枝の骨折端に新しい 関節突起ができたのを確認しており，それも幼若なサル にしかできなかったと述べている。 
清田は10歳以下の脱臼骨折 4 症例に下顎頭の再形生を 認めたが， 13 藏の 2 例は奇形な形態をしていたと報告 し，その文献中に Holtgrave も同様の所見を持ってい ることを記載している。しかし，私の症例では 4 墄で脱 臼骨折を起こした 1 例と，3歳および12歳で偏位骨折を 起こした 2 例に下顎頭の奇形がみられた。脱目骨折の症 例は二股様の double head condyle を呈しており,こ れは受賃後約40日間ゴム牽引が行われたため十分な顎運 動ができず，骨折した関節突起が吸収される前に下顎枝 骨折端と瘉合したためと推察する。また, 偏位骨折の例 は脱臼骨折症例の奇形に比べて軽度であるが, 関節突起 部修復中の顎運動に問題があったのではないかと思われ るが，推察の域をでない

これら 3 症例はすべて関節突起頸部の低位での骨折で あり，それも含めて何らかの原因や障害で修復に時間が かかった場合に奇形が生じやすいのではないかと思われ る.

以上の結果から，小児顓骨骨折に対する治療法として は，従来の当科での治療に妥当性を見い出すことができ た。しかし，骨折線上の函胚に対する配蔍が今後の課題 と考えている。

\section{結}

\section{論}

1961年から1977年までの16年間に久留米大学医学部附 属病院口腔外科を受診した15歳未涩の小愳罘骨骨折患者 60 名について臨床X線学的に钼察し,さらに遠隔調査に 応じた33名について予後を調査し，次のような結果を得 た。

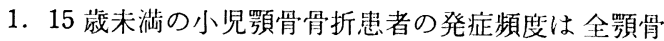
骨折患者の $14.5 \%$ で，5ち下顎骨骨折が約 $96 \%$ を占めた.

2. 性別では 2.8:1 で男罗に多く，年粭別では，5〜 6 筬と13〜14藏に多くみられた。

3. 受伤原因では自動車事故が最も多く半数を占めて いた。性別との関係では自動車事故は $21: 9$, 転落は 11：0 と男胃に多くみられた。年秢では各年路にみられ たが，自動車事故は 5 ～ 6 藏に多く，スポーツによるも のはすべて 9 藏以上であった。

4. 年次别推移で若干增川の倾们がみられ，原因别で も自動車事故が增えているよらであった。

5. 月别では, 12 月，1月， 2 月の冬に少なかった。

6. 他部合併損榎は $38 \%$ に文られ, 頭部外俊が取も多 かった。

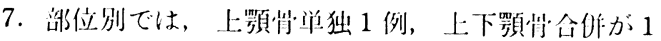
例で残り58例は下顎骨単独例であった。

その骨折線は, 上䋶では 1 例は Le fort I 型で 1 例は 不明，下顎では，単独骨折が32例，重複骨折が21例で骨 折線は大歯小四曾部が最も多く28本，次いで顎関節突起

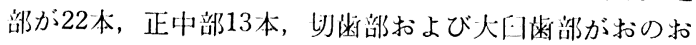

の 7 本，下顓角部および上行枝部が各 2 本であった.

8. 顎関節突起部骨折の MacLennan の分類では, 偏位のないもの 2 例, 偏位骨折 5 例, 転移骨折 2 例, 脱 臼骨折13例であった。

9. 年䐱層による骨折好発部位は，4歳末満では正中

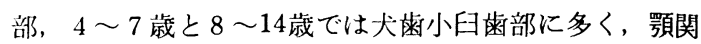
節突起部は全年龉層で高頻度に発症していた。

10. 治䝤法では，観血的整復法が17例（1 例上顎）に 全例骨体部骨折で買関節突起部骨折では全て非钼血的整 復であった。また固定法は，团繞結禁法と連続歯牙結禁 法の行われたものが多く, 前者は 6 歳以下に, 後者 6 歳 以上に多く用いられていた，骨縫合が行われたものが14 例あったがいずれも陳旧例で年齢差はなかった。またい ずれも術中感染等の異常合併症を併発したものはなかっ た.

11. 遠隔調查に応した症例は60例中33例の55\%で，そ の経過年数は最短 9 か月, 最長 15 年 8 か月, 平均 6 年 1 か月であった。

12. 骨折線上にあった永久歯歯胚28歯中 6 歯に米根形 態異常が， $5 ち 2$ 歯に歯冠部石灰化不全を認めた。

13. 歯根形態異常を呈した齿では, 受賃時の歯胚形成 時期, 骨折線の走行, 推血的処置の有無, 歯根数との間 に関係が認められた。すなわち，㐪冠形成以前のもの Type I に属する骨折線の走りを示すもの, 観血的処直 を行ったもの，単根歯に異常を認めた。

14. 曾牙の捻転, 傾斜, 転位が12例にみられたが, 骨 折と関係があると思われたものは 2 例であった。

15. 畨列扰よび咬合所見では，翼常のみられたものは 反対咬合 2 例, 切端咬合, 上鿓前突各 1 例の 4 例にみら れたが，骨折との関係はみられなかった。 また，下顎正 中の偏位が 4 例にみられたが，1 例に骨折との関連がみ られた。

16. 顎関節突起部骨折の 3 例に下買頭の形態異常が認 められたが機能障邫, 顔貌の変形等なく子後は中富の後 遗症判定基準で全例完全治癒であった。

本諭文の要旨は，籁32回日本口院外科学会九州地方部 会ならびに、第26回日本口腔外科学会総会で発表した。

\section{引用文 献}

1) Freid, M.G. and Baden, E.: Management of fracture in children. J Oral Surg 12: 1291391954.

2）渡辺我男，西峌光巳，他：過去10年间のわが教

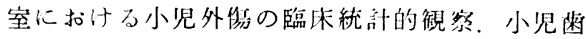
誌 6: 175-179 1968.

3) Rowe, N.L.: Fractures of the facial skeleton in children. J Oral Surg 26: 505-515 1968.

4）烽崳文彦，石川陽二，他：小胃の口腔外㩐。北 
海道菻医会誌 35：22-26 1980.

5) Rowe, N.L.: Fractures of the jaws in children. J Oral Surg 27: 497-507 1969.

6) Khosla, V.M. and Boren, W.: Mandibular fractures in children and their management. J Oral Surg 29: 116-121 1971.

7) Hall, R.K.: Injuries of the face and jaws in children. J Oral Surg 1: 65-75 1972.

8）消田健司：小児䫇骨骨折に閶する臨休的ならび にX線学的研究。口病誌 43：479-508 1976 .

9）西鮂克巳，長畠駿一郎，他：当教空過去15年.間 に扣ける小児下顎骨骨折の臨床統計的微察之予 後について，小児檤誌 16：461-467 1978.

10) MacGregor, A.B. and Fordyce, G.L.: The treatment of fracture of the neck of the mandibular condyle. Brit Dent J 102: 351-357 1957.

11) Thomson, H.G., Farmer, A.W., et al.. Condylar neck fractures of the mandibular in children. Plast Reconstr Surg 34: 452-463 1964.

12) MacLennan, W.D. and Simpson, W.: Treatment of fractured mandibular condylar processes in children. Brit J Plast Surg 18: 4234271965.

13) Leake, D., Doykos, J., et al.: Long-term follow-up of the fractures of the mandibular condyle in children. Plast Reconstr Surg 47: 127-131 1971.

14) Jacobsen, P. U.and Lund, K.: Unilateral over growth and remodeling process after fracture of the mandibular condyle. Scand J Dent Res 80: 68-74 1972.

15) MacLennan, W.D.: Consideration of 180 caces of the typical fractures of mandibular condylar process. Brit J Plast Surg 5: 122-128 1952.

16) McCoy, F.J., Chandler, R.A., et al.: Facial fractures in children. Plast Reconstr Surg 37: 209-215 1966.

17) Adekey, E.O.: Pediatric fractures of the facial skeleton; a survey of 85 cases from Kaduna, Nigeria. J Oral Surg 38: 355-358 1980.

18）小浜源郁，道健一，他：乳児下買骨骨折の骨 周囲線結热応用の 1 例。 口病誌 36: 188-192 1969.

19）宫川喜光，小林八州男，他：顎骨骨折に関与る 臨床的統計钼察。口病誌 24：389-398 1957 .

20）城山剛彦，棚橋祥次，他：最近 5 ヶ年間のわが 教室に扣ける䫇骨骨折の臨床的钼察。渎科医学 21: 689-697 1958.

21）織田健太郎：下顎骨学折の統計的微察。蔌科月 報 18：452，519，573，626，1955.

22）野間弘康，河内 博，他：顎顔面骨骨折の統計 的钼察. 日口外誌 18：450-455 1972 .

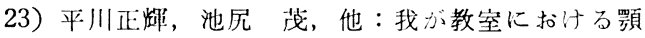
骨骨折患者群についての統計的钼察。踭界展望
16: 910-915 1959.

24) Keniry, A.J.: A survey of Jaw fractures in children. Brit J Oral Surg 8: 231-236 1970.

25) Morgan, W.C.: Pediatric mandibular fractures. J Oral Surg 40: 320-326 1975.

26) Fortunato, M.A., Fielding, A.F., et al.: Facial bone fractures in children. Oral Surg 53: 225-230 1982.

27）消水正嗣：小児の顎骨骨折。日画俨論 348 : 1325-1334 1971.

28）金田敏郎：光弹性実験に上る下䫇骨の力学的研 究. 口病誌 26：2029-2056 1959 .

29）市来英雄, 鹤丸高久: 囲緼結然法支使用した孚 呪䫇骨骨折の 1 症例。日幽評論 305: 308-309 1969.

30）谷口䨝正, 高橋彰, 他: 小児下顎骨骨折に扰 汁万㖽骨固定法。口科誌 18：780-784 1969.

31) Bradley, J.L.: Fracture of the mandibular of a child; report of case. J Oral Surg 11: 1461491953.

32) Rakower, W., Protzell, A., et al.: Treatment of displaced condylar fractures in children; report of cases. J Oral Surg 19: 517-521 1961.

33) Kaplan, S.I. and Mark, H.I. Bilateral fractures of the mandibular condyles and fractures of the symphysis menti in an 18-month-old child. Oral Surg 15: 136-147 1962.

34) Hoopes, J.E., Wolfort, F.G., et al.: Operative treatment of fractures of the mandibular condyle in children. Plast Reconstr Surg 46: 357-362 1970.

35) Becker, C.W.H. and Sheridan, F.: Condylectomy of a comminuted condylar fracture and treatment of an associated fracture of the right lower jaw on a child 11 years of age. Oral Surg 7: 460-463 1954.

36) York, B.V.: Management of mandibular fracture in 3-week-old infant: report of case. J Oral Surg 28: 857-859 1970.

37) Lenstrup, K.: On injury by fractures of the jaw to teeth in course of formation Acta Odont Scand 13: 181-202 1955.

38) Ranta, R. and Ylipaavalnieme P.: The effect of jaw fractures in children on the development of permanent teeth and the occlucion. Proc Finn Dent Sec 69: 99-104 1973.

39) Larsen, O.D. and Nielsen A.: Mandibular fractures II . A follow-up study of 229 patients. Scand J Plase Reconstr Surg 10: 219-226 1976.

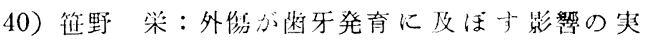
験。口病誌 6：235-260 1932.

41) Lewars, P.H.D.: Some aspects of fractures of the horizontal ramus of the mandible in children. Brit J Plast Surg 10: 218-235 1957. 


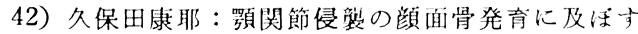
影敕に関衣万実験的研究。口病誌 27：368-391 1960.

43) Lovasko, J.H. and Laskin, D.M.: Facial growth after condylectomy and alloplastic condylar replacement. J Oral Surg 36: 6856921978.

44）中後忠男, 石沢命久, 他: 頭部X線規格正貌写 真分析法に関多万正中線の決定について。日矯 曾誌 20: 131-157 1951.

45) Blevins, C. and Gorest, R.J.: Fractures of the mandibular condyloid process: results of conservative treatment in 140 patients. J Oral Surg 19: 392-407 1961.

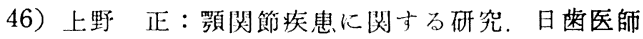
会誌 12: 7-14 1959 .

47）中富虹次郎：顎関節突起鬲折の臨床的研究。口 科誌 13: 132-155 1964 .

48) Walker, R.V.. Traumatic mandibular condylar fracture dislocation. Am J Surg 100: 8508631960.

49) MacLennan, W.D.: Fractures of the mandible in children under the age of six years. Brit J Plast Surg 9: 125-128 1956. 